

\section{Sumário}

I. INTRODUÇÃO

The Datasphere and the Law: New Space, New Territories ...................................III Jean-Sylvestre Bergé e Stéphane Grumbach

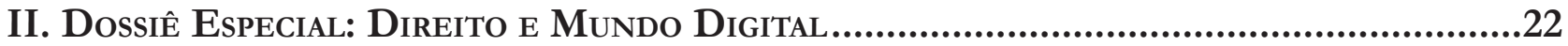

A. Criptomoedas e tecnologia blockchain ......................................................................23

Passado, presente e futuro da CRiptografia forte: DesenVolvimento tecnológico e

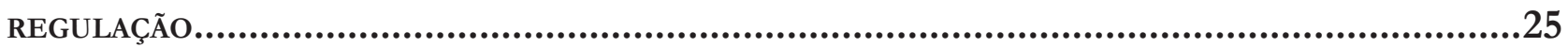
Jacqueline de Souza Abreu

Tratamento JuRídico Das CRIPTOMOEDAS: A DiNÂMiCA DOS BitCOINS E O CRIME DE LAVAGEM

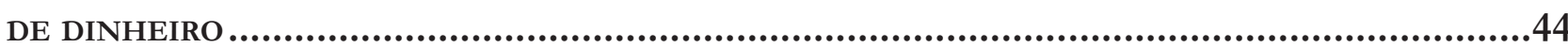
Mariana Dionísio de Andrade

TERRITÓRIO DAS CRIPTOMOEDAS: LIMITES À REGULAMENTAÇÃo ESTATAL QUANTO À CIRCULAÇÃO DE MOEDAS NO CIBERESPAÇO E POSSÍvEIS ALTERNATIVAS ..................................................61 Ranidson Gleyck Amâncio Souza

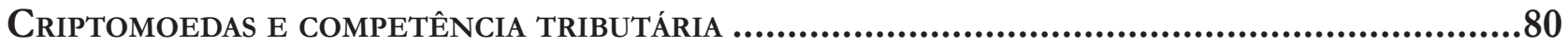
Guilherme Broto Follador

BitCoIn E A (IM)POSSIBILIDAde DE SUA PROIBIÇÃO: UMA VIOLAÇÃo À SOBERANIA Do EsTAdo?106 Rodrigo Valente Giublin Teixeira e Felipe Rangel da Silva

BlockChain e Agenda 2030

Danielle Mendes Thame Denny, Roberto Ferreira Paulo e Douglas de Castro

A reconstruÇão da JURISDição PELO ESPAÇO Digital: REDES SOCIAIS, BLOCKCHAIN E CRIPTOMOEDAS COMO PROPULSORES DA MUDANÇA.

Maria Edelvacy Pinto Marinho e Gustavo Ferreira Ribeiro

B. Proteção de dados e provedores de Internet

O tempo e O espaço. Fragmentos do marco Civil da internet: paradigmas de Proteção DA DIGNIDADE HUMANA 160 Maria Celeste Cordeiro Leite dos Santos e Marilene Araujo 
O PRojeto de Lei de PRoteção de dAdos PEssoais (PL 5276/2016) NO MUNDO do Big DATA: O FENÔMENO DA DATAVEILLANCE EM RELAÇÃo À UTILIZAÇÃO DE METADADOS E SEU IMPACTO NOS DIREITOS HUMANOS ................................................................................... 185

Elias Jacob de Menezes Neto, Jose Luis Bolzan de Morais e Tiago José de Souza Lima Bezerra

DignidADE HUMANA NA WEBESFERA GOVERNAMENTAL BRASILEIRA...................................200 Luciana Cristina Souza

CiberespaÇo E CONTEÚdo OFENSIVO GERAdo POR TERCEIROS: A PROTEÇão DOS DiREITOS DE PERSONALIDADE E A RESPONSABILIZAÇÃo CIVIL DOS PROVEDORES DE APLICAÇÃO, À LUZ DA JURisprudênCIA do Superior Tribunal de JustiçA................................................ 217 Cristiano Colombo e Eugênio Facchini Neto

A responsabilidade CIVIL pelos atos autônomos da INTEligÊnCIA ARTIFICIAL: NOTAS iniciais sobre a resolução do Parlamento Europeu ...........................................239 Thatiane Cristina Fontão Pires

Rafael Peteffi da Silva

SHARENTING, LIBERDADE DE EXPRESSÃO E PRIVACIDADE DE CRIANÇAS NO AMBIENTE DIGITAL: O PAPEL DOS PROVEDORES DE APLICAÇÃo NO CENÁRIO JURÍDICO BRASILEIRO. 256 Fernando Büscher von Teschenhausen Eberlin

THE DICHOTOMY BETWEEN SMART METERING AND THE PROTECTION OF CONSUMER'S PERSONAL DATA IN BRAZILIAN LAW..

Lucas Noura Guimarães

O CYBERBULlying E OS LIMITES DA LIBERDADE DE EXPRESSÃO 295 Janile Lima Viana, Cinthia Meneses Maia e Paulo Germano Barrozo de Albuquerque

O Supremo Tribunal Federal e o discurso de ódio nas redes sociais: exercício de DIREITO VERSUS LIMITES À LIBERDADE DE EXPRESSÃO

Carlo José Napolitano e Tatiana Stroppa

ANÁlise COMPARAdA DE ESTRATÉgIAS DE ENFRENTAMENTO A “REVENGE PORN” PELO MUNDO .... 334 Natália Neris, Juliana Pacetta Ruiz e Mariana Giorgetti Valente

USO INDEVIDO DE REDES SOCIAIS E APLICATIVOS DE MENSAGENS INSTANTÂNEAS NO AMBIENTE LABORAL 
ENSAIO SOBRE A PROMESSA JURÍDICA DO ESQUECIMENTO: UMA ANÁLISE A PARTIR DA PERSPECTIVA DO PODER SIMBÓliCo DE BOURDIEU 368 Joana Machado e Sergio Negri

UMA AGENDA PARA O DIREITO AO ESQUECIMENTO NO BRASIL. 384 Bruno de Lima Acioli e Marcos Augusto de Albuquerque Ehrhardt Júnior

NÃo AdIANTA NEM TENTAR ESQUECER: UM ESTUdo SOBRE O DIREITO AO ESQUECIMENTO...... 412 José Augusto Fontoura Costa e Geraldo Miniuci

A aplicaÇão do direito ao ESQUecimento aos agentes delitivos: uma ANÁlise aCERCA da PONDERAÇÃO ENTRE O DIREITO À IMAGEM E AS LIBERDADES DE EXPRESSÃO E DE INFORMAÇÃO437 Paulo Afonso Cavichioli Carmona e Flávia Nunes de Carvalho Cavichioli Carmona

DiREITO AO ESQUECIMENTO: NA SOCIEDADE INFORMACIONAL HÁ ESPAÇO PARA O EPÍLOGO DA MÁQUINA DE TORTURA KAFKIANA?

Alexandre Antonio Bruno da Silva e Marlea Nobre da Costa Maciel

ESQUECIMENTO, INTERNET E “PREFERÊNCIA” DA INFORMAÇÃO: POSSIBILIDADES DE APLICAÇÃO DA DOUTRINA DOS PREFERRED RIGHTS DA JURISPRUDÊNCIA NORTE-AMERICANA AO CASO BRASILEIRO 484

Maria Vital da Rocha, Isaac Rodrigues Cunha e Karin de Fátima Rodrigues Oliveira

D. Propriedade intelectual 510

Direitos AUtorais E MÚSICA: TECNOLOGIA, DiREITO E REGUlaÇão Marcia Carla Pereira Ribeiro, Cinthia Obladen de Almendra Freitas e Rubia Carneiro Neves

Direito AUTORAL NA CIBERCUlTURA: UMA ANÁLISE Do ACESSO AOS BENS IMATERIAIS A PARTIR DAS LICENÇAS CREATIVE COMMONS 4.0.

Gabriela Maia Rebouças e Fernanda Oliveira Santos

E. Políticas públicas e novas tecnologias.

SALTO DIGITAL NAS POLÍTICAS PÚBLICAS: OPORTUNIDADES E DESAFIOS .561 Marcelo D. Varella, Clarice G. Oliveira e Frederico Moesch

Fostering E-gOVERnMENT IN BRAZIL: A CASE STUdY OF DIGITAL CERTIFICATION ADOPTION.585 Lamartine Vieira Braga

DEMOCRATIZAÇÃo NA ERA Digital: DESAFIOS PARA UM DiÁlOgo CONSCIENTE E IGUALITÁRIO.602 Raquel Cavalcanti Ramos Machado e Laura Nathalie Hernandez Rivera 
REDES SOCIAIS E CROWDSOURCING CONSTITUCIONAL: A INFLUÊNCIA DA CIBERDEMOCRACIA SOBRE A GÊNESE E A INTERPRETAÇÃO DE NORMAS CONSTITUCIONAIS ...................................... 618 Igor Ajouz

MARCo CIVIL DA INTERNET E POLÍTICA PÚbliCA DE TRANSPARÊNCIA: UMA ANÁLISE DA E-DEMOCRACIA E DO COMPLIANCE PÚBLICO.

Juliana Costa Zaganelli e Wallace Vieira de Miranda

Políticas públicas bRasileiras de COMPUTAÇÃo EM NUVEM: ANÁLISE DOCUMENTAL dos RELATÓRIOS DO GLOBAL CLOUD COMPUTING SCORECARD

Lucas dos Santos Costa e Marcos Fernando Machado de Medeiros

O uso monopolista do Big Data POR EMpresas de aplicativos: políticas públicas para UM DESENVOLVIMENTO SUSTENTÁVEL EM CIDADES INTELIGENTES EM UM CENÁRIO DE ECONOMIA CRIATIVA E DE LIVRE CONCORRÊNCIA...................................................................6 672 José Antonio Remedio e Marcelo Rodrigues da Silva

1. Introdução

2. A urbanização das cidades e a sociedade em rede: economia criativa, colaborativa e compartilhada como formas de concretização de funções sociais da cidade.

4. Concorrência e Big Data Business relevantes às Smart Cities: estudo de caso envolvendo a aquisição do Waze pelo Google

5. Considerações finais

Referências

III. OUTROS TEMAS

COMO SALVAR O SISTEMA DE REPERCUSSÃo GERAL: TRANSPARÊNCIA, EFICIÊNCIA E REALISMO NA escolha do Que o Supremo Tribunal Federal vai Julgar.. .696 Luís Roberto Barroso e Frederico Montedonio Rego

Precariedade do sistema penitenciário brasileiro como base temática para a proibição OU LEGALIZAÇÃO DAS DROGAS. 715

Lilian Rose Lemos Rocha e José Eduardo Cardozo

A terceira margem do constitucionalismo republicano: uma Crítica A Frank Michelman. .732

Daniel Barcelos Vargas

Medida PRovisória E CONTROLE DE CONSTITUCIONALIDADE: RELEVÂNCIA, URGÊNCIA E PERTINÊNCIA TEMÁTICA

Clarice G. Oliveira e José Levi Mello do Amaral Júnior 
ОвJETO E CONCEITO DO DIREITO ADMINISTRATIVO: REVISÃo CRÍTICA...................................765 Carlos Bastide Horbach

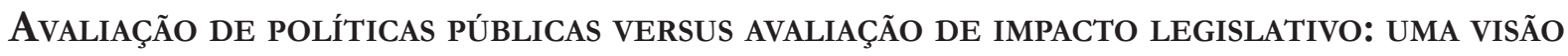
DICOTÔMICA DE UM FENÔMENO SINGULAR

Aparecida de Moura Andrade e Héctor Valverde Santana

LOS AVATARES DEL INTERÉS DEFINIDO EN TÉRMINOS DE PODER EN LA FORMULACIÓN DE LAS POLÍTICAS PÚBLICAS

Louis Valentin Mballa

CONSEQUENCIALISMO JUdicial NA MODUlaÇão DE EFEITOS DAS DECISÕES DECLARATÓRIAS DE INCONSTITUCIONALIDADE NOS JULGAMENTOS DE DIREITO TRIBUTÁRIO 819

Fernando Leal e Daniela Gueiros Dias

JudicializaÇão da SAÚde: A dignidade da PESSOA HuMana E A ATUAÇão do Supremo Tribunal Federal no caso dos medicamentos de alto custo

Fabricio Veiga Costa, Ivan Dias da Motta e Dalvaney Aparecida de Araújo 


\title{
Esquecimento, internet e "preferência" da informação: possibilidades de aplicação da doutrina dos preferred rights da jurisprudência norte-americana ao caso brasileiro*
}

\author{
Forgottening, internet and "preference" of \\ information: Possibilities of application of \\ the doctrine of preferred rights of the North \\ American jurisprudence to the Brazilian case
}

\author{
Maria Vital da Rocha** \\ Isaac Rodrigues Cunha*** \\ Karin de Fátima Rodrigues Oliveira ${ }^{* * * *}$
}

* Recebido em 31/10/2017

Aprovado em 15/12/2017

** Pós-Doutoranda em Direito, na Faculdade de Direito da Universidade de Lisboa. Doutorado em Direito Civil pela Universidade de São Paulo; "Perfezionamento" em Direito Romano na Universidade de Roma La Sapienza, graduação em Direito pela niversidade Federal do Ceará e graduação em Letras pela Universidade Estadual do Ceará. Atualmente é Professora Adjunta de Direito Civil, na Faculdade de Direito da Universidade Federal do Ceará. Email: mavital@secrel.com.br

*** Mestre em Direito pela Universidade Federal do Ceará, com Área de Concentração em Ordem Jurídica Constitucional. Bacharel em Direito pela Universidade Federal do Ceará. Professor da Faculdade do Maciço de Baturité/CE. Assessor Jurídico da Promotoria de Justiça de Acarape/CE. Email: isaac.rodrigues. cunha@gmail.com

**** Bacharel em Ciências da Computação pela Universidade Federal do Ceará. Técnica em Informática pela Escola Estadual de Ensino Profissionalizante Elsa Maria Porto Costa Lima. Tem experiência em Ciências da Computação. Email: karindefatima@gmail.com

\section{Resumo}

A internet se configurou como meio precípuo de comunicação entre as pessoas, criando um "espaço virtual" praticamente sem arestas ou limites, com igualmente ilimitadas informações. Com efeito, o assim chamado "direito ao esquecimento" acaba por ser tensionado nesse cenário, quando acontecimentos delicados, ocorridos há tempos, são facilmente (re)encontrados nas páginas pela rede. Nesse sentido, questiona-se a aplicabilidade à realidade jurídica brasileira da Teoria dos Preferred Rights ("liberdades preferidas"), tal qual concebida na doutrina e, especialmente, na jurisprudência constitucional estadunidense, quando do confronto das prerrogativas fundamentais que requerem um acesso livre e desimpedido às informações postas na rede com aquelas que reclamam respeito à privacidade, à intimidade e à responsabilidade por tais informações. A originalidade do trabalho reside em investigar se deve, por que deve e quando deve haver uma "posição de preferência" do direito à informação sobre o direito ao esquecimento. A metodologia seguiu a leitura de livros, artigos de periódicos e documentos, classificando-se a pesquisa como bibliográfico-documental, pura e descritiva. Partiu-se dos conceitos basilares envolvendo os direitos em conflito e seu tratamento na jurisprudência pátria para investigar quão adequado seria defender a preferência de um sobre o outro. Como conclusões, considera-se que somente deve haver preferência da premissa coletiva de acesso à informação sobre a particular garantia de esquecimento quando: i) as informações possuírem relevância política ou social; ii) o meio utilizado para divulgação, no exercício da liberdade de expressão, preserva o nome e a imagem do interessado; e iii) o caráter cívico da informação supera sua exploração econômica.

Palavras-chave: Esquecimento. Internet. Preferred rights. 


\section{Abstract}

The internet has been configured as the primary means of communication between people, creating a virtual space with virtually no boundaries or limits, with equally unlimited information. Indeed, the so-called "right to oblivion" ends up being strained in this scenario, when delicate facts, long occurred, are easily (re) found on the pages by the network. In this sense, the applicability to the Brazilian legal reality of the preferred rights theory, as conceived in doctrine and especially in US constitutional jurisprudence, is questioned when confronting the fundamental prerogatives that require free access and unimpeded to the information posted on the network with those that claim respect for privacy, privacy and responsibility for such information. The originality of the work lies in investigating whether it should, why and when there should be a "preferred position" of the right to information on the right to forgetfulness. The methodology followed the reading of books, articles of periodicals and documents, classifying the research as bibliographic-documentary, pure and descriptive. It was based on the basic concepts involving the rights in conflict and their treatment in the jurisprudence of the mother country to investigate how adequate it would be to defend the preference of one over the other. As conclusions, it is considered that there should only be preference of the collective premise of access to information on the particular guarantee of forgetfulness when: i) the information has political or social relevance; ii) the medium used for the dissemination, in the exercise of freedom of expression, preserves the name and image of the person concerned; and iii) the civic character of the information surpasses its economic exploitation.

Keywords: Right to be let alone. Internet. Preferred rights.

\section{INTRODUÇÃo}

Como consequência ou mesmo necessidade da assim chamada "Sociedade da Informação", a internet conta já com diversas ferramentas de busca, como o Google $e^{\mathbb{R}}$, $B_{i n g}{ }^{\mathbb{R}}$ e o $A s k^{\circledR}$, as quais permitem aos usuários acessarem conteúdo demasiado diverso e de forma rápida e intuitiva. Os resultados gerados são um conjunto de sites, blogs, redes sociais, páginas e portais dos mais diversos, arquivos de imagem, música, vídeo e documentos para download etc. Tais resultados estão diretamente relacionados com as tags, com as palavras-chave pesquisadas, as quais orientam os famosos algoritmos de busca.

Com efeito, das mais variadas "páginas" tornadas públicas na World Wide Web, na "rede mundial”, sistema de documentos salvos em hipermídia — ou seja, reunidos de várias mídias num ambiente computacional, e que são interligados e executados via internet —, toda e qualquer informação pode ser obtida. A informação estará ali e será por um longo período de tempo alcançada pelo buscador por meio de seus algoritmos, dado que o armazenamento, em geral, tende a ser resistente ao tempo, a menos que seja modificada ou deletada a informação buscada pelos hosts, i. e. pelas máquinas ou computadores responsáveis por veicular tais dados.

Todo esse conteúdo, vinculado a um autor ou a diversos autores, em muito informa e entretém seus usuários, ao passo que possibilita a todos o acesso a um volume inimaginável de informações. Segundo estudo publicado na revista Science Express, calcula-se que a quantidade de informações produzidas na internet entre 1986 e 2007 chegou mesmo à ordem dos exabytes ${ }^{1}$ - i. e., $10^{18}$ bytes ou um bilhão de gigabytes: é tanta informação que nem é possível, com a tecnologia atual, catalogar-se a tudo. ${ }^{2}$

1 HILBERT, Martin. How much information is there in the world? Science Daily, Science News, 11 fev. 2011. Disponível em: <https://www.sciencedaily.com/releases/2011/02/110210141219.htm>. Acesso em: 20 set. 2017.

2 A pesquisa também demonstrou que, inobstante a tecnologia atual não consiga catalogar tudo o que está posto na internet como dados, essa mesma tecnologia permite, porém, que a humanidade possa armazenar mais e mais informação, dado que a capacidade de armazenamento cresce em torno de $25 \%$ ao ano (percentual levando em conta uma capacidade astronômica de armazenagem). 
Ocorre que, nesse universo ou multiverso de informações, nem todos os dados tornados públicos possuem, realmente, veracidade ou compromisso com a verdade, tampouco relevância social. Tantas vezes não pautadas em questões nobres, como a informação ou a formação das pessoas, nem objetivando um lucro lícito (como no webmarketing ou on-line shopping, por exemplo), muitas publicações via internet apenas têm a intenção de que o maior número de pessoas as acesse e compartilhe, talvez em virtude dos "valores" da sociedade atual, em que pesa "ser parte de um todo" ou a busca por um sentimento de pertença etc. Nesse afã por views e likes's , acabam sendo publicados conteúdos distorcidos, descompromissados com a verdade dos fatos.

Como um dos exemplos mais emblemáticos nesse sentido, o caso de Fabiane Maria de Jesus, "linchada" em 2014 sob suspeita de praticar "bruxaria" ou "magia negra" contra crianças, vindo a falecer aos 5 dias de maio daquele ano: sua morte teria sido "fundada" em boatos de uma página da rede social Facebook ${ }^{\circledR}$, que veiculara um falso retrato falado de uma mulher a qual teria sequestrado crianças em Guarujá, São Paulo, para rituais ocultistas. ${ }^{4}$ Após três anos de sua morte, com apenas 5 (cinco) condenados entre os muitos envolvidos, Fabiane pode dar nome à lei que advier do PL n. 7544/2014, que aumenta de 1/3 (um terço) a pena de quem incitar crimes via internet, criando o tipo penal de "incitação virtual ao crime". 5

Por outro lado, diante de tal cenário, percebe-se diuturna a atenção doutrinária à eficácia e respeito aos chamados "direitos da personalidade" ou mesmo "direitos fundamentais da personalidade" especialmente no âmbito da internet, sobretudo depois da promulgação da Lei n. 12.965, de 23 de abril de 2014, a qual estatuiu o chamado "Marco Civil da Internet" no Brasil, antecedida, porém, entre outras legislações nesse sentido, pela Lei n. 12.737/2012 (“Lei Carolina Dieckman”), que tipificou delitos informáticos.

Nesse sentido, o presente trabalho dedica-se a vislumbrar os contornos constitucionais do confronto entre o chamado direito ao esquecimento com o que se tem construído na doutrina em torno de um direito fundamental à informação, que se pretende efetivar, sobretudo, via internet, a qual também tem reconhecida sua essencialidade como meio e instrumento. No dizer de Victor Augusto de Paula, a própria internet pode ser compreendida como um "instrumento otimizador" dos direitos fundamentais", razão pela qual uma potencial lesão, por meio de tal instrumento, carece de atenção pela academia.

O presente artigo, destarte, investiga a dialética existente entre a semântica desses dois direitos tidos, doutrinariamente, por fundamentais, apontando o que seria determinante para a "preferência" de um em relação ao outro, a fim de evitar o absolutismo de um ou do outro enquanto direito ou liberdade fundamental. Nesse sentido, chega-se (ou retorna-se, porque já não recente) a teoria construída na jurisprudência constitucional estadunidense, qual seja, a Teoria dos Preferred Rights, "direitos preferidos" ou "direitos de preferência" , como proposta para estabelecer em que sentido o acesso à informação via internet deve prevalecer sobre o esquecimento.

A estrutura do presente artigo se inaugura com uma abordagem, a partir de revisão de literatura no assunto, do "estado da arte", em se tratando dos conceitos fundamentais de "direito à informação" e "direito

3 Palavras que, valendo tal "profecia", certamente acabarão por serem aportuguesadas, deixando de ser meros anglicismos, estrangeirismo, de tão utilizadas. Não por menos, a palavra web, pode ser encontrada no dicionário Houaiss da Língua Portuguesa, como "nome pelo qual a rede mundial de computadores internet se tornou conhecida a partir de 1991, quando se popularizou devido à criação de uma interface gráfica que facilitou o acesso e estendeu seu alcance ao público em geral". HOUAISS, Antônio; VILLAR, Mauro; FRANCO, Francisco Manoel de Mello. Dicionário Houaiss da língua portuguesa. Rio de Janeiro: Objetiva, 2009. p. 1962. 4 D'AGOSTINO, Rosanne. Três anos depois, linchamento de Fabiane após boato na web pode ajudar a endurecer lei. G1, É ou não é?, São Paulo, 1 abr. 2017. Disponível em: <https://g1.globo.com/e-ou-nao-e/noticia/tres-anos-depois-linchamento-defabiane-apos-boato-na-web-pode-ajudar-a-endurecer-lei.ghtml>. Acesso em: 25 set. 2017.

5 BRASIL. Projeto de lei da câmara n. 7455, de 13 de maio de 2014. Brasília: Congresso Nacional, 2014. Disponível em: <http://www. camara.gov.br/proposicoesWeb/fichadetramitacao?idProposicao=615049>. Acesso em: 15 set. 2017.

6 PAULA, Víctor Augusto Lima de. O acesso à internet como instrumento otimizador de direitos fundamentais. 2014 . 147 f. Dissertação (Mestrado) - Universidade Federal do Ceará, Faculdade de Direito, Programa de Pós-Graduação em Direito, Fortaleza-CE, 2014. Disponível em: <http://www.repositoriobib.ufc.br/000019/00001999.pdf>. Acesso em: 30 out. 2017.

7 Alguém há que chama, mais desenvolvidamente, de "doutrina da posição preferencial". 
ao esquecimento". Segue a verificação do tratamento que é conferido pela jurisprudência brasileira quando do conflito entre tais direitos, sobretudo na alçada do Superior Tribunal de Justiça, continuando, na seção de número três, com a análise da teoria da posição preferencial norte-americana, resgatando suas origens e aplicações. Como hipótese de trabalho, elege-se a ideia de que a informação, para que o acesso a ela seja preferido a seu esquecimento, deve possuir um quantum cívico, social e responsável, além de resguardar o nome e a identidade de quem quer "ser deixado sozinho".

Em sede de metodologia, classifica-se a pesquisa, quanto ao tipo ou quanto às fontes utilizadas, como bibliográfica e documental, por basear-se na literatura já publicada sobre o assunto, explicando o problema com base em referências teóricas, além de utilizar igualmente como fontes documentos oficiais, sobretudo leis e julgados. Classifica-se, também, como pura quanto à utilização dos resultados, destinando-se, precipuamente, a ampliar o conhecimento dos autores no assunto. Classifica-se, por último, como descritiva, por descrever a realidade ou problemática a que se dedica. ${ }^{8}$

\section{ACESSO À INFORMAÇÃo E ESQUECIMENTO COMO DIREITOS ANTAGÔNICOS E SEU TRATAMENTO NA DOUTRINA E JURISPRUDÊNCIA BRASILEIRA}

Conforme salientam Diniz, Costa e Medeiros, a internet vem ressignificando o mundo dito "globalizado", sendo a "responsável pela maior parte das mudanças que vêm acontecendo nas formas como vemos e tratamos [a] informação", correspondendo à "base que auxilia a constante evolução da tecnologia da informação". ' Nos dizeres de Karl-Heinz, Ladeur, a internet foi que "quebrou ou minou todas as fronteiras entre formatos, comunicação individual e de massa, conteúdo de comunicação e tecnologias de telecomunicações." ${ }^{10}$ Nesse cenário, percebe-se que tanto o acesso à internet, enquanto meio de comunicação, quanto o acesso às informações nela constantes, configuram-se como direitos, e direitos ditos fundamentais, tamanha a relevância que lhes reconhece a própria semântica constitucional brasileira.

Ocorre que, nesse mesmo cenário, as premissas constitucionais e legais em torno da privacidade e da intimidade dos cidadãos, que também "fazem parte do ordenamento jurídico brasileiro [...] nem sempre são respeitadas". ${ }^{11}$ Dessa sorte, ao passo que a imagem da internet como espaço político digital vem-se avultando mais e mais, é ela marcada por infindáveis contradições, sobretudo no caso dos discursos de ódio ou mesmo dos crimes cibernéticos mais variados. ${ }^{12}$

Realmente se fala numa "ágora digital", numa "ciberdemocracia" numa "República.com", na acepção de Cass Sustein ${ }^{13}$, ou, como chama Antonio-Enrique Pérez Luño ${ }^{14}$, numa “teledemocracia”, na qual o acesso à

8 BASTOS, Núbia Maria Garcia. Introdução à metodologia do trabalho acadêmico. 4. ed. Fortaleza: Nacional, 2006.

9 DINIZ, Igor Vinicius de Lucena; COSTA, Lucas dos Santos; MEDEIROS, Marcos Fernando M. Utilização da computação em nuvem no poder legislativo: percepções dos gestores e entraves ao uso. Rev. Bras. Polít. Públicas, Brasília, v. 7, n. 1, p. 264-285, 2017. Disponível em: <https://www.publicacoesacademicas.uniceub.br/RBPP/article/view/4586/pdf>. Acesso em: 6 dez. 2017. 10 LADEUR, Karl-Heinz. New institutions for the protection of privacy and personal dignity in internet communication - "information broker", "private cyber courts" and network of contracts. Revista Brasileira de Políticas Públicas, Brasília, v. 10, n. 1, p. 281-296, 2013. Disponível em: <https://www.publicacoesacademicas.uniceub.br/RBPP/article/view/2531/pdf_1>. Acesso em: 6 dez. 2017.

11 SANTANA, Héctor Valverde; VIANA, Rafael Souza. O compartilhamento de dados e informações pessoais de consumidores: o abuso dos fornecedores e as propostas apresentadas no PLS 181/2014. Rev. Bras. Polít. Públicas, Brasília, v. 7, n. 1, p. 246-263, 2017. Disponível em: <https://www.publicacoesacademicas.uniceub.br/RBPP/article/view/4579/pdf>. Acesso em: 5 dez. 2017. 12 Como exemplo emblemático (e sintomático) dos últimos meses, houve polêmico caso de racismo nas redes sociais envolvendo a filha do casal de artistas Bruno Gagliasso e Giovanna Ewbank. No dia 27 de novembro de 2017, Day McCarthy, figura controversa que se autoproclama socialite, "dedicara" vídeo postado em seu blog pessoal para desferir um sem número de ofensas à criança Titi, em razão de sua etnia africana, tendo chegado a chamá-la de "macaca".

13 SUNSTEIN, Cass. Republic.com. Princeton: University Press, 2001.

14 LUÑO, Antonio-Enrique Pérez. Teledemocracia, ciberciudadania y derechos humanos. Revista Brasileira de Políticas Públicas, Brasília, v. 4, n. 2, p. 10, 2014. Disponível em: https://www.publicacoesacademicas.uniceub.br/RBPP/article/view/2835/pdf>. Acesso em: 5 dez. 2017. 
internet e a toda e qualquer informação nela contida são pontos fulcrais, especialmente numa sociedade que se diz "da informação", "informatizada". No dizer de Luño ${ }^{15}$, para as gerações de hoje, indignadas ou não com o estado das coisas, "está tudo na internet", e o que não está não vale a pena conhecer. Salienta o mesmo autor que as Novas Tecnologias (NT) e as Tecnologias da Informação e Comunicação (TIC) "têm produzido novas formas de viver os valores democráticos, mas, como contraponto, têm engendrado também novos riscos para o exercício e a tutela das liberdades". ${ }^{16}$

Frisa ainda Pérez Luño constantes intromissões na intimidade das pessoas, aquilo que chama de "colonização da vida privada", ocasionadas inegavelmente por conta do (ab)uso das tecnologias. Para o autor, tais ingerências "têm suscitado constante inquietude cívica nas sociedades avançadas", sendo característica, para ele, do desenvolvimento tecnológico atual, a geração de "novos fenômenos de agressão aos direitos e liberdades". ${ }^{17}$ Tal problemática intensifica-se, de um lado, por conta do incontrolável tráfego de informações característico da internet, que parece não possuir limitações, e, por outro lado, em virtude de que a legislação brasileira, "ao tratar do tráfico de dados e informações pessoais, [...] está (diferentemente do que ocorre nos principais países da América do Norte e da Europa) estagnada no que diz respeito à proteção de dados pessoais, carecendo de norma específica para tanto". ${ }^{18}$

Dessa forma, se vislumbram as infinitas possibilidades de confronto entre aqueles que buscam determinado assunto, bastante delicado, e atinente à vida pregressa de alguém, geralmente uma figura pública ou mesmo política - atitude esta albergada pelo manto do direito de acesso à informação - e aqueles que, ao contrário, querem que tal assunto permaneça sepultado no passado, e sem se poder exumar de qualquer forma - atitude, por sua vez, albergada pelo que já se chamara no presente trabalho de "direito ao esquecimento". Nesse sentido, cumpre justamente se alcançar a forma e o conteúdo desses direitos — de ser informado e de ser esquecido - , a partir de quando se poderá verificar em que medida um limita ou mesmo se sobrepõe (é "preferido") ao outro.

\subsection{Um direito fundamental (de acesso) à informação}

Cumpre relembrar que o assim chamado "direito à informação", "direito de acesso à informação" ou "direito de ser informado", encontrou já guarida em documentos internacionais do porte da Declaração Universal dos Direitos Humanos de 1948, em que se encontra, em seu art. 19, que "todo ser humano tem direito à liberdade de opinião e expressão; esse direito inclui a liberdade de, sem interferência, ter opiniões e de procurar, receber e transmitir informações e ideias por quaisquer meios e independentemente de fronteiras" ${ }^{\prime 19}$. Em virtude de de tal previsão, tal direito é, historicamente, associado ao também fundamental direito de liberdade de expressão. Por outro lado, na esteira do pensamento de José Ramón Sabau, Dias e Custódio aduzem que o direito à informação "se configura como uma ramificação (diferenciada) da liberdade de expressão e, por conseguinte, da dignidade humana". ${ }^{20}$

15 LUÑO, Antonio-Enrique Pérez. Teledemocracia, ciberciudadania y derechos humanos. Revista Brasileira de Politicas Públicas, Brasília, v. 4, n. 2, p. 10, 2014. Disponível em: https://www.publicacoesacademicas.uniceub.br/RBPP/article/view/2835/pdf>. Acesso em: 5 dez. 2017.

16 LUÑO, Antonio-Enrique Pérez. Teledemocracia, ciberciudadania y derechos humanos. Revista Brasileira de Politicas Públicas, Brasília, v. 4, n. 2, p. 10, 2014. Disponível em: https://www.publicacoesacademicas.uniceub.br/RBPP/article/view/2835/pdf>. Acesso em: 5 dez. 2017.

17 LUÑO, Antonio-Enrique Pérez. Teledemocracia, ciberciudadania y derechos humanos. Revista Brasileira de Políticas Públicas, Brasília, v. 4, n. 2, p. 10, 2014. Disponível em: https://www.publicacoesacademicas.uniceub.br/RBPP/article/view/2835/pdf>. Acesso em: 5 dez. 2017.

18 SANTANA, Héctor Valverde; VIANA, Rafael Souza. O compartilhamento de dados e informações pessoais de consumidores: o abuso dos fornecedores e as propostas apresentadas no PLS 181/2014. Rev. Bras. Polít. Públicas, Brasília, v. 7, n. 1, p. $238,2017$. Disponível em: <https://www.publicacoesacademicas.uniceub.br/RBPP/article/view/4579/pdf>. Acesso em: 5 dez. 2017.

19 ORGANIZAÇÃO DAS NAÇÕES UNIDAS. ASSEMBLEIA GERAL. Declaração universal dos direitos bumanos, Resolução 2017, A, III, de 10 de dezembro de 1948. Disponível em: <https://www.unicef.org/brazil/pt/resources_10133.htm>. Acesso em: 6 dez. 2017.

20 DIAS, Felipe da Veiga; CUSTÓDIO, André Viana. O discurso expansivo-punitivo dos meios de comunicação e sua influência 
Mas o que diferenciaria o acesso à informação dos demais direitos humanos e, especialmente, da liberdade de expressão? Numa primeira leitura, a diferença residira, apenas, na titularidade desse ou daquele direito, ao passo que a pessoa que se quer livre para expressar-se sobre determinado assunto não necessariamente coincidiria com aquela que se deseja livre para acessar as informações em torno do mesmo assunto. Daí os autores indicarem que "o diferencial principal desse direito específico para a sua matriz é o conteúdo, ou seja, a transmissão da informação impõe o dever (mesmo subjetivo) de veracidade", imprimindo ao direito de liberdade de expressão verdadeiro "compromisso ético-jurídico", o qual se estende, segundo eles, inclusive "à órbita da liberdade de imprensa, ambos funcionando com o objetivo informativo, mas constitucionalmente orientado". ${ }^{21}$

Nesse sentido, para Dias e Custódio, o direito à informação, ou de acesso à informação, originalmente tido sob uma bandeira defensiva, com vistas a "proteger o direito de informar" — então mais ligado à liberdade de expressão —, carrega, na atualidade, "a proteção da busca por informações”, uma proteção aos meios e canais de acesso à informação. ${ }^{22}$ Dessa sorte, o conceito de "direito à informação" ultrapassaria, assim, a mera concepção como liberdade individual, como liberdade privada, que exigiria uma postura meramente "negativa" do Estado, uma postura absenteísta. Ao contrário, na atualidade, quando permeada totalmente pelo princípio democrático, a informação recebe contornos políticos, sociais, cívicos, bem além da concepção privatista que se lhe poderia atribuir: "o direito à informação e à liberdade de imprensa têm natureza coletiva, portanto, não compõem um direito individual dos profissionais da área de comunicação e sim uma proteção da coletividade que será informada". 23

Fato é que, tanto mais intensificada a busca por mais e mais informações, como é característica do que ocorre na internet, esse caráter cívico acaba por ser ainda mais ressaltado, como inferem Dias e Custódio, para quem “o aprimoramento tecnológico possibilitou à informação alcançar outro nível de importância e relevância social, seja por compor parte da vida (dividida em mundo real e virtual) nas relações entre seres humanos, ou pela necessidade de consumo informativo". ${ }^{24}$ Esse "novo suporte" de proteção da busca ou do acesso às informações encontra resguardo, por sua vez, em diversos meios jurídicos, especialmente, como citam os autores, a proteção constitucional do direito à informação e a vedação aos monopólios comunicativos/informativos. ${ }^{25}$

Diante disso, como asseveram Boff e Dias ${ }^{26}$, a doutrina costuma compor o direito à informação com,

na formação da agenda das políticas públicas de combate à criminalidade de crianças e de adolescentes no Brasil. Revista Brasileira de Politicas Públicas, Brasília, v. 3, n. 1, p. 93, jan./jun. 2013. Disponível em: <https://www.publicacoesacademicas.uniceub.br/RBPP/ article/view/2162/pdf>. Acesso em: 7 dez. 2017.

21 DIAS, Felipe da Veiga; CUSTÓDIO, André Viana. O discurso expansivo-punitivo dos meios de comunicação e sua influência na formação da agenda das políticas públicas de combate à criminalidade de crianças e de adolescentes no Brasil. Revista Brasileira de Políticas Públicas, Brasília, v. 3, n. 1, p. 93, jan./jun. 2013. Disponível em: <https://www.publicacoesacademicas.uniceub.br/RBPP/ article/view/2162/pdf>. Acesso em: 7 dez. 2017.

22 DIAS, Felipe da Veiga; CUSTÓDIO, André Viana. O discurso expansivo-punitivo dos meios de comunicação e sua influência na formação da agenda das políticas públicas de combate à criminalidade de crianças e de adolescentes no Brasil. Revista Brasileira de Políticas Públicas, Brasília, v. 3, n. 1, p. 93, jan./jun. 2013. Disponível em: <https://www.publicacoesacademicas.uniceub.br/RBPP/ article/view/2162/pdf>. Acesso em: 7 dez. 2017.

23 DIAS, Felipe da Veiga; CUSTÓDIO, André Viana. O discurso expansivo-punitivo dos meios de comunicação e sua influência na formação da agenda das políticas públicas de combate à criminalidade de crianças e de adolescentes no Brasil. Revista Brasileira de Políticas Públicas, Brasília, v. 3, n. 1, p. 93, jan./jun. 2013. Disponível em: <https://www.publicacoesacademicas.uniceub.br/RBPP/ article/view/2162/pdf>. Acesso em: 7 dez. 2017.

24 DIAS, Felipe da Veiga; CUSTÓDIO, André Viana. O discurso expansivo-punitivo dos meios de comunicação e sua influência na formação da agenda das políticas públicas de combate à criminalidade de crianças e de adolescentes no Brasil. Revista Brasileira de Políticas Públicas, Brasília, v. 3, n. 1, p. 93, jan./jun. 2013. Disponível em: <https://www.publicacoesacademicas.uniceub.br/RBPP/ article/view/2162/pdf>. Acesso em: 7 dez. 2017.

25 DIAS, Felipe da Veiga; CUSTÓDIO, André Viana. O discurso expansivo-punitivo dos meios de comunicação e sua influência na formação da agenda das políticas públicas de combate à criminalidade de crianças e de adolescentes no Brasil. Revista Brasileira de Politicas Públicas, Brasília, v. 3, n. 1, p. 97, jan./jun. 2013. Disponível em: <https://www.publicacoesacademicas.uniceub.br/RBPP/ article/view/2162/pdf>. Acesso em: 7 dez. 2017.

26 BOFF, Salete Oro; DIAS, Felipe da Veiga. O acesso à informação no campo digital: uma análise entre a sociedade da infor- 
pelo menos, 3 (três) facetas distintas, mas que se complementam, quais sejam: i) um direito de prestar informações, e de fazê-lo por meio dos canais existentes, notadamente dos meios de comunicação (acepção mais próxima da liberdade de expressão), "respeitando-se requisitos semelhantes aos impostos à liberdade de imprensa, como clareza e veracidade"; ii) o direito de busca e acesso à informação, "em respeito à pluralidade informativa na formação das convicções humanas, sem permitir lesões a outros direitos fundamentais"; e iii) o direito de ser informado. Essa tridimensionalidade aponta, assim, para a densidade da estrutura em que assiste tal direito.

Nesse sentido, Carlos Roberto Siqueira Castro assevera que o direito à informação constitui, ao lado do direito à vida, "a mais fundamental das prerrogativas humanas, na medida em que o saber determina o entendimento e as opções da consciência, o que distingue os seres inteligentes de todas as demais espécies que exercitam o dom da vida" ${ }^{27}$ Consiste, igualmente, no dizer do mesmo autor, em requisito primordial para qualquer regime democrático, uma vez sabido que os indivíduos, e mesmo as sociedades desinformadas, alheios às principais informações em matéria de Estado, de governo etc., acabam excluídos dos processos políticos, "proscritos das condições da cidadania que dão impulso aos destinos das nações". ${ }^{28}$ Com efeito, foi encimando tal estrutura, e importando o tanto que se já discutia em torno do acesso à informação como direito humano fundamental no plano internacional, que a Constituição Federal de 1988 insculpiu, em seu inciso XIV, o direito fundamental brasileiro de acesso à informação ${ }^{29}$, reiterando-o reiterou em seu art. 220 , caput e parágrafos. ${ }^{30}$

Posta tal fundamentação, inclusive constitucional, não se pode esquecer que é justamente o caráter social e cívico hodiernamente impresso à informação que lhe vai exigir um exercício, ao mesmo tempo, responsável, compromissado com a veracidade das informações e, inegavelmente, respeitando a privacidade e a intimidade alheias, especialmente por conta dos limites que a lei impõe. É justamente esse compromisso simultaneamente ético e social, vale adiantar, que vai fundamentar uma "preferência" do acesso à informação ou à liberdade discursiva (free speech) tal qual se concebeu na jurisprudência constitucional estadunidense, isto porque, tradicionalmente, se reconheceu tanto ao exercício individual quanto ao coletivo de tal direito uma posição preferencial em relação aos demais direitos fundamentais. No dizer de Luís Roberto Barroso, ainda em 2004, "na verdade, tanto em sua manifestação, como especialmente na coletiva, entende-se que as liberdades de informação e de expressão servem de fundamento para o exercício de outras liberdades, o que justifica uma posição de preferência", quando confrontadas com outros direitos fundamentais individualmente considerados. ${ }^{31}$

A cautela, porém, impede a "absolutização" de qualquer conceito ou classificação — especialmente em matéria de direitos, sobretudo em se tratando dos direitos humanos fundamentais, sendo mais improvável ainda um critério absoluto aplicável em face do conflito entre estes. Nesse sentido, feito um esboço do

mação e a sociedade de risco, Revista de Estudos Jurídicos, ano 16, n. 23, p. 329, 2012. Disponível em: < https://dialnet.unirioja.es/ descarga/articulo/4816043.pdf>. Acesso em: 6 dez. 2017.

27 CASTRO, Carlos Roberto Siqueira. A constituição aberta e os direitos fundamentais: ensaios sobre o constitucionalismo pós-moderno e comunitário. 2. ed. Rio de Janeiro: Forense, 2010. p. 437.

28 CASTRO, Carlos Roberto Siqueira. A constituição aberta e os direitos fundamentais: ensaios sobre o constitucionalismo pós-moderno e comunitário. 2. ed. Rio de Janeiro: Forense, 2010. p. 437.

29 "XIV - é assegurado a todos o acesso à informação e resguardado o sigilo da fonte, quando necessário ao exercício profissional;". BRASIL. Constituição da República Federativa do Brasil de 1988. Disponível em: <http://www.planalto.gov.br/ccivil_03/ constituicao/constituicaocompilado.htm>. Acesso em: 28 jun. 2017.

30 “Art. 220. A manifestação do pensamento, a criação, a expressão e a informação, sob qualquer forma, processo ou veículo não sofrerão qualquer restrição, observado o disposto nesta Constituição. $\int 1^{\circ}$ Nenhuma lei conterá dispositivo que possa constituir embaraço à plena liberdade de informação jornalística em qualquer veículo de comunicação social, observado o disposto no art. $5^{\circ}, \mathrm{IV}, \mathrm{V}, \mathrm{X}, \mathrm{XIII}$ e XIV. $\ 2^{\circ}$ É vedada toda e qualquer censura de natureza política, ideológica e artística”. BRASIL. Constituição da República Federativa do Brasil de 1988. Disponível em: < http://www.planalto.gov.br/ccivil_03/constituicao/constituicaocompilado.htm>. Acesso em: 28 jun. 2017.

31 BARROSO, Luís Roberto. Colisão entre liberdade de expressão e direitos da personalidade: Critérios de ponderação: Interpretação constitucionalmente adequada do Código Civil e da Lei de Imprensa. Revisa de Direito Privado, v. 18, p. 105, abr. 2004. 
direito à informação, cumpre agora auscultar os contornos constitucionais do direito com o qual tem a prática mostrado constante confronto, qual o chamado "direito ao esquecimento". Após o necessário resgate conceitual de tais prerrogativas fundamentais, é que se analisará se é possível "preferir” um ao outro e como têm decidido dos tribunais acerca disso.

\subsection{O esquecimento como direito da personalidade (ou direito de "humanidade")}

O direito ao esquecimento estaria incluído entre os chamados "direitos da personalidade", nomenclatura que ainda reclama revisões, havendo quem prefira falar em "direitos de humanidade", categorias em que estariam incluídos "todos os direitos imprescindíveis aos homens, inalienáveis, inatos, indisponíveis", os quais estariam "ligados à ideia da garantia do mínimo existencial, do essencial aos seres humanos, sendo anteriores ao Estado, ou seja, inerentes à sua natureza" ${ }^{\text {"32 }}$.

Com efeito, inegável é a repercussão da tutela de tais direitos na vida das pessoas, sobretudo com o reconhecimento, pelos tribunais, pela jurisprudência, de novos direitos da personalidade, processo característico da própria evolução desta categoria de direitos. Conforme aduzem Santana e Viana, uma primeira evolução normativa em torno dos direitos da personalidade fora, justamente, a superação do paradigma da proteção apenas da integridade física dos cidadãos, em respeito ao clássico direito à vida, quando se passou a considerar, igualmente, o direito a uma vida livre, "o direito de aproveitá-la, gozá-la e de ser deixado em paz”. ${ }^{3}$

Por outro lado, Luño assevera que as próprias contradições geradas, na atualidade, pelas tecnologias e, sobretudo, pela internet, fizeram surgir um "movimento da doutrina jurídica e da jurisprudência dos países com maior grau de desenvolvimento tecnológico tendente ao reconhecimento de novos direitos humanos dirigidos a evitar a contaminação tecnológica das liberdades", ${ }^{34}$ quando se fala em "liberdade informática", "faculdade de autodeterminação na esfera informática", na proteção dos dados pessoais, entre outros direitos tendentes a responder a tais questões.

Nesse sentido, percorrendo as mutações — ou ampliações — que tais direitos vêm sofrendo com a contemporaneidade jurídica, há quem fale na existência de um direito que concorra com a permanência ou divulgação após longo período de olvido de certas informações sobre alguém, sobretudo no caso em que tais dados gerem algum dano à personalidade: escândalos passados, crimes cometidos ou sofridos há tempos, cuja lembrança, após anos ou mesmo décadas é desgostosa para todos os envolvidos. É quando se fala, diante de tais casos, na existência de um certo "direito ao esquecimento". Como espécie ou subespécie do grande gênero dos direitos de personalidade, vale frisar que tal direito, por mais recente que pareça ser, já vem sendo debatido há certo tempo, inclusive pela doutrina pátria.

Como já bem salientara Otavio Luiz Rodrigues Junior ${ }^{35}$, o Brasil vem discutindo-o desde os anos 1990. $\mathrm{O}$ autor defende que as discussões sobre o tema no país iniciaram-se bem antes de serem alcançadas pela

32 SANTANA, Héctor Valverde; VIANA, Rafael Souza. O compartilhamento de dados e informações pessoais de consumidores: o abuso dos fornecedores e as propostas apresentadas no PLS 181/2014. Rev. Bras. Polít. Públicas, Brasília, v. 7, n. 1, p. 241-242, 2017. Disponível em: <https://www.publicacoesacademicas.uniceub.br/RBPP/article/view/4579/pdf>. Acesso em: 5 dez. 2017. 33 SANTANA, Héctor Valverde; VIANA, Rafael Souza. O compartilhamento de dados e informações pessoais de consumidores: o abuso dos fornecedores e as propostas apresentadas no PLS 181/2014. Rev. Bras. Polít. Públicas, Brasília, v. 7, n. 1, p. 246, 2017. Disponível em: < https://www.publicacoesacademicas.uniceub.br/RBPP/article/view/4579/pdf>. Acesso em: 5 dez. 2017. E complementam: "A sociedade tomou consciência de que não se estava diante de um direito qualquer, tornando imperativa a sua tutela, razão pela qual engloba o rol de direitos da personalidade e, no Brasil, a proteção à privacidade está expressamente prevista no Código Civil Brasileiro e na Constituição Federal. Foi considerada como direito fundamental e um dos requisitos para se assegurar a dignidade da pessoa humana." 34 LUÑO, Antonio-Enrique Pérez. Teledemocracia, ciberciudadania y derechos humanos. Revista Brasileira de Políticas Públicas, Brasília, v. 4, n. 2, p. 11, 2014. Disponível em: https://www.publicacoesacademicas.uniceub.br/RBPP/article/view/2835/pdf>. Acesso em: 5 dez. 2017.

35 RODRIGUES JÚNIOR, Otavio Luiz. Brasil debate direito ao esquecimento desde 1990. Consultor Jurídico, 27 nov. 2013. Disponível em: <http://www.conjur.com.br/2013-nov-27/direito-comparado-brasil-debate-direito-esquecimento-1990>. Acesso em: 10 jul. 2017. 
jurisprudência do Superior Tribunal de Justiça em 2013, como se verá adiante. Para ele, a doutrina brasileira já vinha, há mais de duas décadas, pincelando teorias no assunto, porque encontráveis "artigos e livros no Brasil que cuidam, de modo direto ou incidental, do "direito ao esquecimento"'36, de que arrola o autor os principais pesquisadores.

No início dos anos 1990, Edson Ferreira da Silva e Luís Alberto David Araújo, em trabalhos distintos, tangenciaram o tema trazendo as ideias de Raymond Lindon, em que se tem o direito ao esquecimento como um dos pilares da privacidade. Em 1994, Sidnei Agostinho Beneti mencionou um direito ao esquecimento dos delitos cometidos por conta da prescrição, em clara aproximação do tema com o Direito Penal. Têmis Limberger, por sua vez, em 2002, defendia que as informações bancárias de um cliente não poderiam permanecer a todo momento expostas, por integrarem o sigilo da pessoa. ${ }^{37}$

Salienta o autor, nessas primeiras incursões doutrinárias no tema, que o direito ao esquecimento transitava entre o Direito do Consumidor e o Direito Penal, sem que se lhe atribuísse um liame qualquer com os já conhecidos direitos da personalidade. $\mathrm{Na}$ atualidade, o tema é encampado de forma mais sensível. Levanta-se que a tecnologia da informação, no nível a que chegou, impede um pleno exercício desse direito. Nega-se o caráter de res nullius às informações postas ao público, devendo ser assegurado ao titular destas informações o direito de restringir-lhes o acesso. Fica clara a conexão do direito ao esquecimento com a proteção à intimidade e à privacidade.

Ocorre que, mesmo sendo debatido por décadas e já tendo chegado às discussões das cortes superiores, ainda é muito impreciso o balanceamento entre tal direito ao esquecimento e outros com que recorrentemente colide, especialmente as liberdades clássicas de expressão e informação. No dizer de Ramos Filho, percebem-se postos nesses confrontos, a "liberdade de imprensa, de um lado, e os atributos da personalidade humana, tais como a intimidade, a privacidade, a honra e a imagem, sem mencionar o princípio da dignidade da pessoa humana, de outro". ${ }^{38}$ Nesse sentido, inúmeros são os casos em que, mesmo após várias décadas do acontecimento de um fato que desabone a reputação de uma pessoa, alguém surge para resgatar tal memória já há tanto esquecida, sepultada na história, por meio de uma notícia, de uma reportagem, até mesmo de um artigo científico, o que tem sido bastante recorrente na internet. É quando se fala em "uma colisão entre direitos fundamentais. ${ }^{39}$

Com efeito, sabe-se que os direitos da personalidade acabaram por receber, tradicionalmente, adornos mais privatistas, adstritos às liberdades individuais, aos direitos civis que compunham a chamada Primeira Geração dos Direitos Fundamentais, sobre os quais esclarece Paulo Bonavides:

Os direitos de primeira geração ou direitos de liberdades têm por titular o indivíduo, são oponíveis ao Estado, traduzem-se como faculdades ou atributos da pessoa e ostentam uma subjetividade que é seu traço mais característico enfim, são direitos de resistência ou de oposição perante o Estado. ${ }^{40}$

36 RODRIGUES JÚNIOR, Otavio Luiz. Brasil debate direito ao esquecimento desde 1990. Consultor Jurídico, 27 nov. 2013. Disponível em: <http://www.conjur.com.br/2013-nov-27/direito-comparado-brasil-debate-direito-esquecimento-1990>. Acesso em: 10 jul. 2017.

37 RODRIGUES JÚNIOR, Otavio Luiz. Brasil debate direito ao esquecimento desde 1990. Consultor Jurídico, 27 nov. 2013 . Disponível em: < http://www.conjur.com.br/2013-nov-27/direito-comparado-brasil-debate-direito-esquecimento-1990>. Acesso em: 10 jul. 2017.

38 RAMOS FILHO, Evilásio Almeida. Direito ao esquecimento versus liberdade de informação e de expressão: a tutela de um direito constitucional da personalidade em face da sociedade da informação. Monografia (Especialização) - Escola Superior da Magistratura do Estado do Ceará, Curso de Pós-Graduação Lato Sensu em Direito Constitucional, Fortaleza: ESMEC, 2014. p. 52. Disponível em: <http://portais.tjce.jus.br/esmec/wp-content/uploads/2014/12/Direito-ao-Esquecimento-vs-Liberdade-deInforma\%C3\%A7\%C3\%A3o.pdf>. Acesso em: 29 jun. 2017.

39 RAMOS FILHO, Evilásio Almeida. Direito ao esquecimento versus liberdade de informação e de expressão: a tutela de um direito constitucional da personalidade em face da sociedade da informação. Monografia (Especialização) - Escola Superior da Magistratura do Estado do Ceará, Curso de Pós-Graduação Lato Sensu em Direito Constitucional, Fortaleza: ESMEC, 2014. p. 53. Disponível em: <http://portais.tjce.jus.br/esmec/wp-content/uploads/2014/12/Direito-ao-Esquecimento-vs-Liberdade-deInforma\%C3\%A7\%C3\%A3o.pdf>. Acesso em: 29 jun. 2017.

40 BONAVIDES, Paulo. Curso de Direito Constitucional. 19. ed. São Paulo: Ed. Malheiros, 2006. p. 563-564. 
Como pressupostos do Estado liberal que se avultava, esses direitos implicavam uma atuação absenteísta do Estado, minuindo sua esfera de atuação na vida privada e conferindo maior liberdade aos particulares, que possuiriam um patamar inatingível de liberdades individuais. Assim, os direitos fundamentais consistiram, incialmente, numa postura de abstenção por parte do Estado liberal, que se afastava da vida privada, no momento em que os chamados direitos fundamentais "de primeira geração" asseguravam as liberdades básicas do indivíduo.

$\mathrm{Na}$ evolução dos direitos da personalidade, podem ser considerados relevantes os seguintes momentos históricos: o cristianismo, ao assentar a ideia de dignidade do homem; a Escola de Direito Natural, ao fixar a noção dos direitos inatos à pessoa como elementos indissociáveis de sua estruturação; e o Iluminismo, com a valorização da pessoa humana diante do poder. ${ }^{41}$

Não obstante a jovialidade do conceito de direitos da personalidade, ou mesmo da personalidade jurídica, verifica-se que sua abordagem se aproxima geralmente da defesa de elementos mínimos de identificação do sujeito, quais sejam o nome, o sobrenome, o patrimônio, o domicílio, a intimidade etc., uma vez que se até chegou a considerar a personalidade civil como expressão jurídica da personalidade psíquica. É o que entende Pontes de Miranda, o qual enquadra a personalidade como fonte não somente do direito, como também da moral, citando Sokolowski, in verbis:

[...] a personalidade é a base commum do Direito e da Moral, sendo, como é, base de outras sciencias, que constituem straficações da cultura, e em que, como bem diz Sokolowski, não ha desenvolvimento de cultura sem o elemento individual: "Die Kulturentwicklung ist obne Vereinigung der Einzelpersonen nicht möglich, ja nicht enimal denkbar. ${ }^{42}$

A personalidade é, assim, identificada no "ser", não no "ter", sendo o patrimônio apenas sua expressão econômica, não jurídica. Em razão disso, goza da titularidade de direitos, abrigando o indivíduo essa personalidade e os direitos dela decorrentes. Assim é que passou a constituir um fenômeno conhecido por "constitucionalização do direito privado", ou ainda por "despatrimonialização do direito privado", no qual, tendo em vista a relevância das relações privadas para a vida do indivíduo, as normas constitucionais passaram a tutelar também assuntos privatistas.

A Constituição Federal de 1988 trata da personalidade atendo-se justamente a seus aspectos personalísticos, no que concerne à dignidade humana, uma vez que assevera direitos e garantias tanto individuais quanto coletivos, além da própria pedestalização do princípio da dignidade da pessoa humana como um dos fundamentos da República. Ademais, Caio Mario da Silva Pereira entende que "o princípio constitucional da igualdade perante a Lei é a definição do conceito geral da personalidade como atributo natural da pessoa humana", cabendo ao Estado proteger a dignidade-personalidade do particular, "sem distinção de sexo, de condição de desenvolvimento físico ou intelectual, sem gradação quanto à origem ou a sua procedência". ${ }^{43}$

Já o novo Código Civil (Lei no 10.406/2002) trata dos Direitos da Personalidade, no mesmo sentido da proteção integral da pessoa humana, prescrevendo-os como inalienáveis, imprescritíveis, intransmissíveis e irrenunciáveis, conforme dispõe seu art. 11, in verbis: "Art. 11. Com exceção dos casos previstos em lei, os direitos da personalidade são intransmissíveis e irrenunciáveis, não podendo o seu exercício sofrer limitação voluntária", sendo tal intransmissibilidade necessária ao caráter íntimo, personalíssimo de tais direitos.

A tais previsões já se poderia, perfeitamente, incorporar uma numerosidade de direitos e garantias decorrentes, consequentes, derivados, uma vez que a tutela da dignidade humana reclama per se a defesa de tudo o que seja necessário para uma vida digna. Mas por que se fala em um direito ao esquecimento? Certamente

41 BITTAR, Carlos Alberto; BITTAR FILHO, Carlos Alberto. Direito civil constitucional. 3. ed. rev. e atual. São Paulo: Revista dos Tribunais, 2003.

42 MIRANDA, Francisco Cavalcanti Pontes de. À margem do direito: ensaio de psychologia jurídica. Rio de Janeiro: Francisco Alves \& Cia, 1912. p. 124.

43 PEREIRA, Caio Mario da Silva. Instituições de direito civil: parte geral. 12. ed. rev. e atual. Rio de Janeiro: Forense, 2007. v. 1. p. 240. 
foi sempre englobada pela ideia de direito fundamental da personalidade a proteção integral do indivíduo, esta compreendida como a inviolabilidade da vida privada, de sua intimidade, do domicílio, de seus documentos, de sua correspondência, de seus dados bancários, entre outros aspectos da individualidade de cada cidadão. Nessa esfera a ser protegida estaria, inclusive, o direito a não ser incomodado ou prejudicado pela relembrança de algo que ficara no passado.

Pontes de Miranda incluía entre os direitos abordados no sétimo volume de seu Tratado de Direito Privado uma porção de direitos que aduziam ao mais íntimo da pessoa, a serem protegidos do que conceituava por "invasão pelos sentidos alheios", questionando mesmo se se protegia a intimidade o direito do particular de segredar coisas íntimas. Nesse sentido, vale transpor, ipsis litteris, o questionamento feito pelo jurista:

$\int 755$. Direito a velar a intimidade

1. Intimidade e invasão pelos sentidos alheios. Cada um tem o direito de se resguardar dos sentidos alheios, principalmente da vista e dos ouvidos dos outros. Não pode A, de fora de casa, usar binóculo, para esguardar o que se passa no quarto de dormir de B, ou no escritório de C, ou no interior da fábrica de D. E certo que o direito à liberdade de domicílio não vai até aí; nem sempre só se viola o direito de personalidade à liberdade de domicílio, nem é preciso que se viole a esse. Pode dar-se a violação do direito a ocultar o seu próprio corpo, que se inclui no de liberdade física, ou a violação do direito ao segredo das relações comerciais, ou do direito patrimonial de autor (maneira de se executar, na fábrica, certa fórmula). Não há dúvida que em todos esses casos há algum interesse no segredo; o segredo entra, apenas, como um dos elementos do suporte fático do ato lesivo. Daí não se pode, todavia, concluir, sem mais, que exista direito à intimidade, autónomo, nem, a fortiori, que exista direito de personalidade à intimidade. (nosso grifo) ${ }^{44}$

De tal constatação, de que não existiria o direito à intimidade per se, mas uma prerrogativa de guardar ou não sua intimidade ao particular, entende o mestre, mais à frente, que deve, na verdade, ser garantida a faculdade entre "fazer e não fazer" em se tratando do segredo, cabendo, apenas, ao titular de tal faculdade escolher entre revelar ou não. Veja-se:

3. Direito a velar a intimidade e liberdade de fazer e de não fazer. O direito a velar a intimidade é, portanto, efeito de exercício da liberdade de fazer e de não fazer: há quem possa não revelar, porque há quem pode não fazer; é a liberdade que está à base disso. Essa liberdade é que pode ser direito de personalidade inato; o direito a velar a intimidade provém dela, como o direito ao sigilo provém da liberdade de se não emitir o pensamento ou o sentimento. O que está em contacto imediato, inato, com a personalidade é o pensar, é o sentir, é o agir; não o segredo, o velamento.

Se existe direito a esses, é porque há liberdade de emitir e de não emitir, de fazer e de não fazer. Exercese aquela, estabelecendo-se o segredo, expressa, tácita ou presumidamente, ou desvendando-se; exercese essa, velando-se o que se passa na intimidade, ou expondo-a ao público. As limitações à intimidade e as limitações à renúncia a ela são, por conseguinte, concernentes à liberdade mesma: todos têm de respeitar mínimo de intimidade (não se pode andar nu, de público, ou em lugar em que possa ser vista a pessoa; nem podem ser de público certos atos corporais) e ao mesmo tempo ninguém pode ser privado de tal mínimo de intimidade (a penetração na vida privada, com inquéritos e buscas, somente se permite nas espécies previstas em lei). (nosso grifo). ${ }^{45}$

Pelo exposto, é uma prerrogativa do direito fundamental à liberdade a garantia do segredo, da intimidade, da própria vida privada, uma vez que é apenas ao "dono" da informação facultado torná-la pública ou não. Tal reflexão, adstrita ao direito geral de liberdade, obviamente moldado pelo ideal de dignidade humana, permite sentenciar: não é necessária a previsão de um direito exclusivo, supostamente autônomo, ao esquecimento. Ele decorre de outros direitos, da liberdade em geral e da própria dignidade humana. É o que se percebe da leitura do Enunciado 531 da VI Jornada de Direito Civil, promovida pelo Conselho de Justiça Federal em 2013:

44 MIRANDA, Francisco Cavalcanti Pontes de. Tratado de Direito Privado: direitos da Personalidade, direito de Família. Rio de Janeiro: Rio de Janeiro, 1955. t. 7. p. 124.

45 MIRANDA, Francisco Cavalcanti Pontes de. Tratado de Direito Privado: direitos da Personalidade, direito de Família. Rio de Janeiro: Rio de Janeiro, 1955. t. 7. p. 126. 
ENUNCIADO 531 - A tutela da dignidade da pessoa humana na sociedade da informação inclui o direito ao esquecimento.

Artigo: 11 do Código Civil

Justificativa: Os danos provocados pelas novas tecnologias de informação vêm-se acumulando nos dias atuais. $\mathrm{O}$ direito ao esquecimento tem sua origem histórica no campo das condenações criminais. Surge como parcela importante do direito do ex-detento à ressocialização. Não atribui a ninguém o direito de apagar fatos ou reescrever a própria história, mas apenas assegura a possibilidade de discutir o uso que é dado aos fatos pretéritos, mais especificamente o modo e a finalidade com que são lembrados. ${ }^{46}$

Ora, é tal direito, em verdade, decorrência de direitos ou garantias anteriores, além das já mencionadas liberdade e dignidade. Decorre o direito ao esquecimento da tutela da intimidade, da honra, da imagem, da vida privada. Isso não importa dizer que seja um direito menos importante ou menos expressivo. Na verdade, o próprio esquecimento em si tem sua relevância, antes mesmo de ser alcançado pelo direito:

Na concepção de Nietzsche, o esquecimento é a força inibidora positiva e ativa, não correspondendo à força inerte, cuja qualidade seria a de impedir que determinadas experiências penetrassem na consciência humana. O esquecimento atuaria como guardião da porta da consciência, zelador da ordem psíquica. A força viva produzida pelo esquecimento possibilitaria à humanidade condições de felicidade, pois bloquearia os efeitos da presentificação do passado. O esquecimento lembra Maria Cristina Franco Ferraz, não apagaria marcas produzidas pela memória, mas antecederia à própria inscrição, impedindo a sua fixação. $\mathrm{Na}$ valorização do esquecimento obtém-se “[...] uma força plástica que é condição de toda a felicidade, identificada à possibilidade de coincidir com o presente, com o instante. Lembra Eduardo Rezende Melo que esta força inibidora experimentada, vivenciada e acolhida mantém os homens imperturbados pelo barulho e lutas presentes no submundo, com isso garantindo a possibilidade do novo -" sem o esquecimento, não poderia haver lugar para a felicidade, a esperança, o orgulho, o presente. ${ }^{47}$

Com efeito, tanto se tem falado na existência de um direito conexo ao esquecimento, ao desejo particular de ser esquecido. Discorda-se disso. Em verdade, o direito ao esquecimento em muito corresponde a um desdobramento, por um lado, do clássico direito de privacidade, mais diretamente, e, por outro lado, de outras garantias de forma mais mediata. Da dignidade humana, por exemplo, quando uma informação resgatada do passado, por trazer de novo à tona situação vexatória, acaba por malferir consideravelmente a integridade moral de qualquer um. Outro exemplo, o não esquecimento de um crime cometido há décadas, pelo que já fora condenado alguém, com pena cumprida etc., entraria em conflito, certamente, com o valor que reclama a vedação da perpetuidade das penas.

Vale frisar, todavia, que o fato de tal direito ser decorrente de outros direitos clássicos não impede que seja utilizada a expressão "direito ao esquecimento", como têm feito a doutrina e a jurisprudência, aqui e alhures. $\mathrm{Na}$ Itália, por exemplo, recebe o nome de "diritto all'oblio" ou "diritto ad essere lasciati soll", datando de mais de 20 anos os debates. O famigerado caso "Bozano" lá recebeu grande destaque como querela em torno do direito ao esquecimento:

Neste caso, uma menina de 13 anos, denominada Milena Suller, foi brutalmente assassinada em 1971. O seu assassino, Lorenzo Bozano, foi processado e condenado pela corte italiana.

Ademais, o programa televisivo italiano "I Grandi Processi", semelhante ao antigo programa brasileiro "Linha Direta", que reproduzia crimes famosos na mídia televisiva, pretendia reproduzir o caso "Bozano".

O programa italiano iria exibir o caso, mesmo sem o consentimento da família da vítima. Vendo-se sem outra alternativa, a família da jovem Suller ingressou na via judicial e requereu tutela de urgência, para que o referido programa não fosse apresentado, invocando o direito ao esquecimento.

46 BRASIL. CONSELHO DA JUSTIÇA FEDERAL. CENTRO DE ESTUDOS JUDICIÁRIOS. VI Jornada de Direito Civil. Brasília: CEJ, 2013. Disponível em: <http://www.cjf.jus.br/cjf/corregedoria-da-justica-federal/centro-de-estudos-judiciarios-1/ publicacoes-1/jornadas-cej/vijornadadireitocivil2013-web.pdf/@@download/file/VIJornadadireitocivil2013\%20web.pdf>. Acesso em: 9 jul. 2017.

47 CARVALHO, Salo de. Antimanual de criminologia. 5. ed. São Paulo: Saraiva, 2013. p. 354-355. 
Ao final, entendeu o Tribunal de Roma que o direito ao esquecimento deveria ser mitigado em prol do interesse histórico que havia no caso, permitindo, assim, a veiculação do programa. ${ }^{48}$

O mesmo vale para o Brasil, com a repercussão que teve o tema com os processos envolvendo a família de Aída Curi e um absolvido da Chacina da Candelária. Os crimes que, mesmo de distantes épocas, até remotas, foram retratados na televisão, o que incomodou os envolvidos. Conforme se perceberá, o STJ se comportou de maneira diferente nesses dois casos, mas em ambos se reconheceu a incidência de um direito ao esquecimento.

\subsection{A posição dupla do Superior Tribunal de Justiça}

Empós quase duas décadas de discussões pela doutrina, finalmente a jurisprudência superior passa a ater-se, em 2013, à questão, quando dois casos de grande repercussão chegaram ao Superior Tribunal de Justiça carregando a expressão "direito ao esquecimento". Os já mencionados casos envolviam a reprodução, pelo programa televisivo "Linha Direta”, da Rede Globo, dos eventos da Chacina da Candelária e do assassinato de Aída Curi. Os autores, insatisfeitos com a exibição de tais programas, ingressaram com suas respectivas ações, chegando ao STJ por meio dos processos RESP n 1.334.097/RJ (Caso “Candelária”) e RESP n⿳ 1.335.153/RJ (Caso “Aída”).

Nesse sentido, Batalha relata:

A Chacina da Candelária foi uma chacina, crime brutal e premeditado, amplamente divulgada pela mídia da época, ocorrida na noite do dia 23 de julho de 1993, próximo à Igreja da Candelária, localizada no centro da cidade do Rio de Janeiro. Neste crime, oito jovens sem teto foram assassinados por policiais militares.

Nesse caso, JGF ajuizou ação de reparação de danos morais em face da TV Globo Ltda., pois foi indiciado como coautor/partícipe da sequência de homicídios ocorridos em 23 de julho de 1993, na cidade do Rio de Janeiro, conhecidos como "Chacina da Candelária", mas que, ao final, submetido a júri, foi absolvido por negativa de autoria.

Entretanto, em junho de 2006, foi ao ar, no programa Linha Direta, contra a vontade expressa do autor JGF, o episódio, que declinou seu nome, tendo sido o autor apontado como um dos envolvidos na chacina, mas que fora absolvido.

A veiculação do seu nome, no terrível episódio, levou a púbico uma situação que já havia superado, reacendendo na comunidade onde residia a imagem de chacinador e o ódio social, ferindo, assim, o seu direito à paz e privacidade pessoal. Houve também prejuízos direitos aos seus familiares.

O autor alegou que essa situação o prejudicou sobremaneira em sua vida profissional, não tendo mais conseguido emprego, além de ter sido obrigado a desfazer-se de todos os seus bens e abandonar a comunidade para não ser morto por "justiceiros" e traficantes e para proteger a segurança de sua família. ${ }^{49}$

Acerca do segundo caso, a mesma autora descreve:

Aída Curi foi vítima de homicídio no ano de 1958 no bairro de Copacabana no Rio de Janeiro. Aída tinha dezoito anos e foi brutalmente abusada sexualmente por três homens, a fim de encobrir o crime os agressores a atiraram do terraço no décimo segundo andar do prédio tentando simular um suicídio. A jovem acabou falecendo em função da queda.

Este crime foi nacionalmente conhecido por força da imprensa da época. Para os irmãos da vítima, autores da ação, a transmissão feita pelo programa "Linha Direita Justiça" do homicídio de sua irmã,

48 BATALHA, Taianne Nayrara Sampaio. Análise do direito ao esquecimento em face do princípio constitucional da vedação das penas de caráter perpétuo. Trabalho de Conclusão de Curso (Graduação) - Universidade Federal do Ceará, Faculdade de Direito, Curso de Direito, Fortaleza, 2014. p. 16. Disponível em: <http://www.repositoriobib.ufc.br/000018/00001848.pdf>. Acesso em: 2 jul. 2017.

49 BATALHA, Taianne Nayrara Sampaio. Análise do direito ao esquecimento em face do princípio constitucional da vedação das penas de caráter perpétuo. Trabalho de Conclusão de Curso (Graduação) - Universidade Federal do Ceará, Faculdade de Direito, Curso de Direito, Fortaleza, 2014. p. 17. Disponível em: <http://www.repositoriobib.ufc.br/000018/00001848.pdf>. Acesso em: 2 jul. 2017. 
após quase sessenta anos, reabriu antigas feridas dos autores.

Os irmãos de Aída alegaram que a emissora explorou a tragédia familiar, e por isso pleitearam danos materiais e à imagem, consistentes na exploração comercial da falecida com objetivo econômico de audiência e publicidade. ${ }^{50}$

Ocorreu que o STJ, pela mesma $4^{a}$ Turma, entendeu, diferentemente, os dois casos, apesar de sua similitude. No caso da Candelária, o STJ entendeu que, em relação à ponderação entre o direito à informação e a proteção da vida privada, dever-se-ia privilegiar o direito ao esquecimento, determinando que se ocultassem o nome e a imagem do interessado, mesmo sendo lícito o exercício da atividade jornalística àquela maneira, mencionando a existência de um "direito ao esquecimento dos condenados que cumpriram pena e dos absolvidos", acolhido em "decorrência da proteção legal e constitucional da dignidade da pessoa humana e das limitações positivadas à atividade informativa". ${ }^{51}$

Já no caso envolvendo a família de Aída Curi, Recurso Especial n. 1.335.153/RJ, os julgadores desconsideraram as alegações dos autores em face da "ausência de contemporaneidade da notícia de fatos passados", cujo resgate, por meio do programa televisivo Linha Direta da Rede Globo reabriria "antigas feridas já superadas quanto à morte de sua irmã, Aída Curi, no distante ano de 1958". ${ }^{52}$ Buscavam, assim, os irmãos Curi ter reconhecido seu direito ao esquecimento, a não ter revivida tal situação pelo programa e contra sua vontade, sofrimento que já ocorrera com a publicidade conferida ao caso há décadas. A corte entendeu que deveria prevalecer a liberdade expressão/informação, justamente por conta da "historicidade" do caso, considerando que "o direito ao esquecimento que ora se reconhece para todos, ofensor e ofendidos, não alcança o caso dos autos, em que se reviveu, décadas depois do crime, acontecimento que entrou para o domínio público, de modo que se tornaria impraticável a atividade da imprensa para o desiderato de retratar o caso Aída Curi, sem Aída Cure". ${ }^{53}$

Nesse sentido, diante de uma aparente anfibologia na postura da mesma turma do STJ que exarou tais decisões contrastantes, cumpre verificar que instrumental teórico haveria de ser levado em conta no sentido de preferir, definitivamente, um direito ao outro — ou tornar mais fácil determinar qual direito entre esses dois em confronto deve prevalecer. Assim, passamos desse conflito de normas, para alcançar, ao fim, interessantíssima teoria de preferência de direitos.

\section{Hierarquização e a "PreferênCia" da liberdade de informaçÃo sobre o direito aO ESQUECIMENTO}

Em linhas gerais, a Lei de Introdução às Normas do Direito Brasileiro estabelece como três os critérios hermenêuticos aplicados quando do conflito de normas, quais sejam, a hierarquia, a temporalidade e a especificidade. No primeiro caso, o critério de prevalência de uma sobre outra é seu nível hierárquico, o tipo de norma, se norma constitucional, lei complementar, ordinária etc., suprimindo a norma superior a validade da inferior. Quanto ao critério temporal, prevalece a norma mais recente. Quanto ao critério especificidade, conforme o nome já denuncia, deve prevalecer a norma mais específica. Ocorre que, conforme têm denota-

50 BATALHA, Taianne Nayrara Sampaio. Análise do direito ao esquecimento em face do princípio constitucional da vedação das penas de caráter perpétuo. Trabalho de Conclusão de Curso (Graduação) - Universidade Federal do Ceará, Faculdade de Direito, Curso de Direito, Fortaleza, 2014. p. 18. Disponível em: <http://www.repositoriobib.ufc.br/000018/00001848.pdf>. Acesso em: 2 jul. 2017.

51 BRASIL. SUPERIOR TRIBUNAL DE JUSTIÇA. Recurso especial n. 1.334.097. Relator: Ministro Luiz Felipe Salomão. Brasília, DF, 28 de maio de 2013. Diário Oficial da União, Brasília, 10 jan. 2013. Disponível em: <http://www.stj.jus.br/SCON/ jurisprudencia/doc.jsp?livre=resp+1334097+RJ\&\&b=ACOR\&p=true\&t=JURIDIC O\&l=10\&i=4>. Acesso em: 10 jul. 2017. 52 CAVAlCANTE, Márcio André Lopes. Direito ao esquecimento. Disponível em: <https://www.buscadordizerodireito.com.br/ jurisprudencia/detalhes/75fc093c0ee742f6dddaa13fff98f104>. Acesso em: 15 dez. 2017.

53 CAVAlCANTE, Márcio André Lopes. Direito ao esquecimento. Disponível em: <https://www.buscadordizerodireito.com.br/ jurisprudencia/detalhes/75fc093c0ee742f6dddaa13fff98f104>. Acesso em: 15 dez. 2017. 
do a doutrina e a jurisprudência pátria, tais critérios são insuficientes ou mesmo inadequados para solucionar o conflito entre regras e princípios, mais ainda quando de regras e princípios fundamentais (constitucionais).

Dessa feita, trazendo tal discussão para o confronto que se vislumbra entre o direito fundamental de acesso à informação e o direito ao esquecimento, questiona-se que critério ou técnica adotar. $\mathrm{O}$ que fazer no caso em que colidem com os direitos amparados por uma mesma semântica constitucional? É possível determinar uma "preferência", um caráter ou uma "posição preferencial" de um em face do outro? Em que casos? É sobre o que passa agora a tratar o presente estudo.

\subsection{Haveria uma hierarquia entre os direitos fundamentais à informação e ao esquecimento?}

Debate recorrente na Teoria dos Direitos Fundamentais e elemento importante de sua consolidação, o problema da hierarquização dos direitos também merece atenção no presente estudo. Nesse sentido, vale recordar o entendimento de Hans Kelsen no sentido de que a hierarquização das normas, envolvidas numa pirâmide jurídica, compreenderia um critério de validade para o qual a norma inferior só seria válida caso respeitasse a superior, tomando a norma como um enunciado puro e com uma colocação definida dentro do escalonamento normativo. ${ }^{54}$

\section{Afirmava Kelsen:}

[...] entre uma norma de escalão superior e uma norma de escalão inferior, quer dizer, entre uma norma que determina a criação de uma outra e essa outra, não pode existir qualquer conflito, pois a norma do escalão inferior tem o seu fundamento de validade na norma do escalão superior. Se a norma do escalão inferior é considerada como válida, tem de considerar-se como estando de harmonia com a norma do escalão superior. ${ }^{55}$

Nessa concepção, em que se também adota o princípio da supremacia da Constituição, é clara a função do texto normativo constitucional como critério de validade do ordenamento, o qual é totalmente irradiado pela Lei Maior. É o argumento principal do chamado controle de constitucionalidade, "consistindo na verificação da compatibilidade entre uma lei ou qualquer ato normativo infraconstitucional e a Constituição". ${ }^{56}$ Assim, surge a questão: ignorando-se as normas insculpidas em leis complementares ou ordinárias, em decretos ou medidas etc., seria possível vislumbrar uma hierarquia entre as próprias normas constitucionais?

Há, entre outras teorias sobre hierarquização, quem defenda a existência de uma hierarquia em razão da matéria, ou seja, teriam maior relevância os dispositivos constitucionais que tratassem de assuntos materialmente constitucionais, como a estruturação do Estado e os direitos e garantias fundamentais, do que os dispositivos que contivessem normas apenas formalmente constitucionais, tratando de assuntos que exorbitassem o conceito clássico de Constituição.

É clara a "superioridade" da norma contida no art. $2^{\circ}$ da Constituição Federal, o qual determina a independência e a harmonia dos três poderes, que a contida no tão famigerado $₫ 2^{\circ}$ do art. 242 , que trata do Colégio Pedro II. ${ }^{57}$ Com efeito, a tese de superioridade das normas materialmente constitucionais foi levantada no constitucionalismo germânico por Krüger e Giese, "para quem é viável que normas constitucionais de teor secundário sejam declaradas inválidas por violação a outras normas constitucionais de maior importância". ${ }^{8}$

54 KELSEN, Hans. Teoria Pura do Direito. Coimbra: Armênio Amado, 1979.

55 KELSEN, Hans. Teoria Pura do Direito. Coimbra: Armênio Amado, 1979. p. 289.

56 BARROSO, Luís Roberto. O controle de constitucionalidade no direito brasileiro: exposição sistemática da doutrina e análise crítica da jurisprudência. 6. ed. rev. e atual. São Paulo: Saraiva, 2012.

57 SILVA, Virgílio Afonso da. Interpretação Constitucional e Sincretismo Metodológico. In: SILVA, Virgílio Afonso da (Org.). Interpretação constitucional. São Paulo: Malheiros, 2009.

58 PEREIRA, Jane Reis Gonçalves. Interpretação Constitucional e Direitos Fundamentai: uma contribuição ao estudo das restrições aos direitos fundamentais na perspectiva da teoria dos princípios. São Paulo: Renovar, 2006. p. 245. 
Assim, é válida a observação de Gilmar Ferreira Mendes:

Embora o texto constitucional não tenha privilegiado especificamente determinado direito, na fixação das cláusulas pétreas $\left(\mathrm{CF}\right.$, art. $\left.60, \sqrt{ } 4^{\circ}\right)$, não há dúvida de que, também entre nós, os valores vinculados ao princípio da dignidade da pessoa humana assumem peculiar relevo (CF, art. $1^{\circ}$, III).

Assim, devem ser levados em conta, em eventual juízo de ponderação, os valores que constituem inequívoca expressão desse princípio (inviolabilidade da pessoa humana, respeito à sua integridade física e moral, inviolabilidade do direito de imagem e da intimidade). ${ }^{59}$

Nesse sentido, vale o questionamento de Ana Maria D’Ávila Lopes:

A Constituição brasileira prevê no art. $60, \int 4^{\circ}$, as matérias que não podem ser objeto de reforma constitucional, ou seja, que se encontram fora dos alcances do poder constituinte derivado. No inc. VI da referida norma, expressamente, estabelece-se que os direitos e garantias individuais correspondem ao que a doutrina denomina de "cláusulas pétreas", normas constitucionais que não podem sofrer emendas.

A pergunta que pode ser feita é: se todos os direitos e garantias fundamentais possuem igual importância, igual hierarquia, por que apenas veda-se a reforma dos individuais? $?^{60}$

Nesse sentido, merecem destaque as diferenciações que se percebem entre as gerações de direitos fundamentais segundo sua própria origem histórica — quando se vislumbra um critério histórico de hierarquização —, segundo a carga valorativa que lhe é atribuída — critério axiológico — e segundo o momento em que se percebe sua efetivação — critério de efetividade.

Há de se falar em hierarquia segundo um argumento histórico pelo grau de "fundamentalidade" que um direito ou garantia fundamental desenvolveu com o passar do tempo - frise-se que a Carta em vigor já conta com mais de vinte e cinco anos. Tal processo se assemelharia à própria evolução dos direitos fundamentais, em gerações ou dimensões ao passar dos anos, chegando a uma terceira que diz respeito às relações difusas de intensificadas pela globalização, em que se vislumbram o direito a um meio ambiente equilibrado, à paz, ao desenvolvimento.

Nesse sentido, Ana Maria D’Ávila Lopes entende que “os direitos de solidariedade, que juridicamente podem ser considerados em estado nascente, caracterizam-se por exigir, para sua conceituação, um maior grau de solidariedade do que os outros pelo fato de serem, ao mesmo tempo, individuais e coletivos".${ }^{61}$ Com efeito, as próprias diferenças na origem, na forma, no conteúdo e nos destinatários dos direitos angariados em cada geração, como reflexos dos momentos históricos em que se desenvolveu cada uma, ocasionariam diferenças também na sua recepção enquanto normas constitucionais. É o que assevera Ana Maria D’Ávila Lopes ao afirmar que:

As diferentes épocas do surgimento, reconhecimento e positivação dessas três categorias de direitos fundamentais revelam que são fenômenos que têm respondido a contextos históricos distintos e a concepções ideológicas diversas. Isso impede que sejam considerados como estritamente equivalentes em seu grau de consenso e legitimidade nacional e internacional, ou como possuidores da mesma natureza. ${ }^{62}$

Dessa sorte, o critério histórico denota sua relevância antes mesmo da configuração de tais direitos e garantias como fundamentais, ou melhor, a historicidade dos direitos humanos é fator determinante inclusive para sua positivação constitucional ("fundamentalização"):

59 MENDES, Gilmar Ferreira. Colisão de direitos fundamentais na jurisprudência do Supremo Tribunal Federal. Repertório de Jurisprudência IOB, São Paulo, v. 1, n. 5, p. 180-181, mar. 2003.

60 LOPES, Ana Maria D’Ávila. Hierarquização de Direitos Fundamentais? Revista de Direito Constitucional e Internacional - IBDC, São Paulo, ano 9, p. 180-181, jan./mar. 2001.

61 LOPES, Ana Maria D’Ávila. Hierarquização de Direitos Fundamentais? Revista de Direito Constitucional e Internacional - IBDC, São Paulo, ano 9, p. 176, jan./mar. 2001.

62 LOPES, Ana Maria D’Ávila. Hierarquização de Direitos Fundamentais? Revista de Direito Constitucional e Internacional - IBDC, São Paulo, ano 9, p. 176, jan./mar. 2001. 
Os direitos humanos seriam fruto de momentos históricos diferentes e a sua própria diversidade já apontaria para a conveniência de não se concentrarem esforços na busca de uma base absoluta, válida para todos os direitos em todos os tempos. Ao invés, seria mais producente buscar, em cada caso concreto, as várias razões elementares possíveis para a elevação de um direito à categoria de fundamental, sempre tendo presentes as condições, os meios e as situações nas quais este ou aquele direito haverá de atuar. Não basta, assim, que um direito encontre bons motivos filosóficos, aceitos no momento, para ser positivado; é indispensável, ainda, o concurso de condições sociais e históricas favoráveis para que se incorpore aos estatutos vinculantes. ${ }^{63}$

Nessa senda, não se deve desconsiderar o argumento histórico como determinante antes, durante e depois da edificação dos direitos e garantias fundamentais num texto constitucional. Por outro lado, uma verificação axiológica ou valorativa dos princípios, direitos e garantias fundamentais aparentemente apontaria para a uma hierarquização - entre o princípio cujos valores se mostrem mais relevantes que o de outro. No dizer de George Marmelstein, ninguém ousaria afirmar que "o princípio da dignidade da pessoa humana 'vale' menos que o princípio da proteção à propriedade", especialmente porque, segundo o autor, "todos os princípios e regras decorrem, ainda que indireta e mediatamente, do princípio-mor da dignidade da pessoa humana". À mesma maneira, num confronto entre princípios constitucionais processuais, essa verificação axiológica acabaria concluindo que ambos decorreriam do princípio do devido processo legal. Dessa forma, seria possível, sim, vislumbrar certa hierarquização dos princípios por conta de sua carga axiológica, ainda que sem apontar que classe de direitos ou garantias teria preferência sobre outra. ${ }^{64}$

Nada obstante, Ana Maria D’Ávila Lopes aponta para o que reconhece como vicissitudes metodológicas de tal critério de diferenciação:

[...] as objeções mais sérias contra uma teoria axiológica são, entretanto, as metodológicas, por ser uma posição que ignora qualquer fundamentação racional — recorre a um sistema de valores de per si não objetivo - podendo provocar arbitrariedades. As objeções metodológicas voltam-se sobretudo contra uma ordem hierárquica de valores e contra as ponderações.

A respeito de uma ordem hierárquica, questiona-se sobre os critérios utilizados na escolha dos valores que farão parte da lista e sobre os critérios utilizados para estabelecer a ordem, isto é, sobre se será uma lista completa e fechada ou aberta. ${ }^{65}$

À mesma maneira, uma terceira diferenciação entre as gerações de direitos fundamentais aponta para o gran de efetividade que um direito ou garantia alcançou desde sua edificação como norma fundamental, a despeito de o $\int 1^{\circ}$ do art. $5^{\circ}$ da $\mathrm{CF} / 1988$ aduzir que "as normas definidoras dos direitos e garantias fundamentais têm aplicação imediata". Ora, a prática cidadã demonstra quão ainda distantes se encontram os ditames constitucionais da realidade política e social do país, o que aproxima a Constituição brasileira da classificação de Lowestein como "constituição nominal", cujas normas ainda não se efetivaram completamente.

Nesse sentido, Ana Maria D’Ávila Lopes discorre que:

Entre as gerações de direitos fundamentais existem claras diferenças. Uma terceira, e que é a mais importante, consiste na afirmação de que, enquanto os direitos da primeira geração possuem aplicabilidade imediata, os da segunda, terceira e quarta gerações estão sujeitos a uma progressividade, traduzida em normas programáticas cuja aplicação concreta encontra-se condicionada ao desenvolvimento de políticas legislativas posteriores, que lhes darão viabilidade material. ${ }^{66}$

63 MENDES, Gilmar Ferreira; COELHO, Inocêncio Mártires; BRANCO, Paulo Gustavo Gonet. Curso de Direito Constitucional. São Paulo: Saraiva, 2007. p. 225.

64 LIMA, George Marmelstein. A hierarquia entre princípios e a colisão de normas constitucionais. Revista Jus Navigandi, Teresina, ano 6, n. 54, fev. 2002. Disponível em: <http://jus2.uol.com.br/doutrina/texto.asp?id=2625>. Acesso em: 7 dez. 2017.

65 LOPES, Ana Maria D'Ávila. Hierarquização de Direitos Fundamentais? Revista de Direito Constitucional e Internacional - IBDC, São Paulo, ano 9, p. 172, jan./mar. 2001.

66 LOPES, Ana Maria D’Ávila. Hierarquização de Direitos Fundamentais? Revista de Direito Constitucional e Internacional - IBDC, São Paulo, ano 9, p. 172, jan./mar. 2001. 
Por outro lado, a jurisprudência da Suprema Corte brasileira, geralmente encimando o princípio da unicidade da Constituição, defende que uma hierarquia entre as normas constitucionais inexiste, conforme o julgado a seguir:

A tese de que há hierarquia entre normas constitucionais originárias dando azo à declaração de inconstitucionalidade de umas em face de outras é impossível com o sistema de Constituição rígida. - Na atual Carta Magna "compete ao Supremo Tribunal Federal, precipuamente, a guarda da Constituição" (artigo 102, "caput"), o que implica dizer que essa jurisdição lhe é atribuída para impedir que se desrespeite a Constituição como um todo, e não para, com relação a ela, exercer o papel de fiscal do Poder Constituinte originário, a fim de verificar se este teria, ou não, violado os princípios de direito suprapositivo que ele próprio havia incluído no texto da mesma Constituição. - Por outro lado, as cláusulas pétreas não podem ser invocadas para sustentação da tese da inconstitucionalidade de normas constitucionais inferiores em face de normas constitucionais superiores, porquanto a Constituição as prevê apenas como limites ao Poder Constituinte derivado ao rever ou ao emendar a Constituição elaborada pelo Poder Constituinte originário, e não como abarcando normas cuja observância se impôs ao próprio Poder Constituinte originário com relação as outras que não sejam consideradas como cláusulas pétreas, e, portanto, possam ser emendadas. Ação não conhecida por impossibilidade jurídica do pedido. ${ }^{67}$

Vale então aqui salientar que não se está a tratar de uma hierarquia entre normas constitucionais, entre os dispositivos da Constituição, mas, sim, entre os valores jurídicos expressados por estes, como bem aduz Ana Maria D’Ávila Lopes:

Há consenso na doutrina brasileira de que as normas constitucionais possuem igual hierarquia, admitindo-se apenas uma diferenciação entre as decorrentes do poder constituinte originário e do derivado. Entretanto, além dessa distinção não é possível realizar qualquer outra, nem ainda em relação às chamadas "cláusulas pétreas".

Nesse sentido, todas as normas constitucionais declaratórias de direitos encontram-se num mesmo nível hierárquico. Contudo, o mesmo não se pode afirmar em relação aos direitos, ou seja, a respeito do conteúdo dessas normas. ${ }^{68}$

Assim, ao apelarmos para a literalidade dos termos bierarquia e bierarquização, em que esta significaria "ato ou efeito de organizar", há que se concluir que, inobstante não se vislumbre uma hierarquia material e formal entre as normas constitucionais, há a possibilidade de, no momento da aplicação dessas normas, realizar-se certa hierarquização entre os valores por elas carregados. Nesse sentido é que passamos a abordar a chamada "teoria da posição preferencial" ou "dos direitos preferidos" (preferred rights/freedoms)

\subsection{A solução do conflito segundo a doutrina da posição preferencial}

Entende-se por hierarquização o processo de "estabelecer hierarquias prévias e rígidas entre os bens constitucionalmente tutelados". ${ }^{99}$ Tal expediente permitiria, ao menos em tese, que "as colisões entre direitos, ou entre estes e bens coletivos, são resolvidas de acordo como pautas preestabelecidas que determinam o peso abstrato e a importância de cada um deles, concluindo-se no sentido da prevalência do que ostenta maior hierarquia" ${ }^{70}$

Cumpre salientar, todavia, que os critérios determinantes de tal hierarquia - como os já abordados na secção anterior — não consubstanciam um sistema infalível de determinação da superioridade de uma

67 BRASIL. SUPREMO TRIBUNAL FEDERAL. Adi n. 815/DF. Relator: Min. MOREIRA ALVES, 28 de março de 1996. Órgão Julgador: TRIBUNAL PLENO. Diário da Justiça, 10 maio 1996. Disponível em: < https://stf.jusbrasil.com.br/jurisprudencia/744338/acao-direta-de-inconstitucionalidade-adi-815-df>. Acesso em: 29 out. 2017.

68 LOPES, Ana Maria D’Ávila. Hierarquização de Direitos Fundamentais? Revista de Direito Constitucional e Internacional - IBDC, São Paulo, ano 9, p. 169, jan./mar. 2001.

69 PEREIRA, Jane Reis Gonçalves. Interpretação Constitucional e Direitos Fundamentai: uma contribuição ao estudo das restrições aos direitos fundamentais na perspectiva da teoria dos princípios. São Paulo: Renovar, 2006. p. 243-244.

70 PEREIRA, Jane Reis Gonçalves. Interpretação Constitucional e Direitos Fundamentai: uma contribuição ao estudo das restrições aos direitos fundamentais na perspectiva da teoria dos princípios. São Paulo: Renovar, 2006. p. 244. 
norma constitucional sobre outra. Nesse sentido, adverte sobriamente Jane Reis Gonçalves Pereira que "as teorias que propugnam hierarquias imóveis dos direitos fundamentais são problemáticas tanto do ponto de vista filosófico quanto do ponto de vista jurídico". ${ }^{71}$

Merecendo maior destaque o último aspecto — o jurídico — no dizer da autora, pelo fato de que, "no quadro de constituições rígidas, não há elementos normativos que permitam estabelecer relações de prevalência incondicionada entre os direitos", a Constituição Federal de 1988 não comporta tal ideia. Caso existisse tal possibilidade, de que os direitos nela previstos fossem hierarquizados in abstracto, "as preferências deveriam ser estabelecidas pelo próprio constituinte". ${ }^{72}$

E arremata:

Isso porque a priorização irrestrita de certos direitos em detrimento de outros traz subjacente uma escolha por determinada teoria da justiça, tendo, assim, um inegável caráter ideológico. E, embora seja certo que a interpretação constitucional não é imune à ideologia e a juízos morais, admitir que opções valorativas não previstas constitucionalmente sejam cristalizadas e perpetuadas por meio de hierarquias jurisprudenciais absolutas implicaria menosprezar o papel do constituinte democrático. A não previsão destas hierarquias no texto constitucional visa exatamente conferir flexibilidade ao processo hermenêutico, e seria um contrassenso que este restasse enrijecido, com base nas preferências axiológicas dos intérpretes. (PEREIRA, 2006, p. 248). ${ }^{73}$

É então que desponta a ideia de "preferred rights" ("direitos privilegiados") ou "preferred freedoms" ("liberdades privilegiadas"), para a qual alguns direitos e garantias fundamentais ocupariam "posições preferenciais" em relação a outros direitos e garantias fundamentais. Tal ideia, melhor aportuguesada como "doutrina da posição preferencial", desenvolveu-se dos entendimentos da Suprema Corte estadunidense. Sobre tal doutrina, discorre Letícia Campos Velho Martel:

A doutrina da posição preferencial significa, pois, a hierarquização dos Direitos Fundamentais protegidos pelo devido processo legal e a inserção de alguns em posição privilegiada em relação a outros. Em que pese todos possuírem caráter de fundamentalidade, uns são apostos em local cimeiro, tomados como de maior peso de per si. Então, os Direitos Fundamentais que assumem o mais alto posto na hierarquização correspondem aos dotados de posição preferencial. Diante da privação destes, usar-se-á o escrutínio estrito; na ausência deles, usar-se-á o teste da mera razoabilidade. ${ }^{74}$

Por sua vez, Jane Reis Gonçalves Pereira fala num "escalonamento abstrato", a ser realizado justamente entre os bens e interesses tutelados pelos direitos fundamentais, como uma forma de ponderação, não se tratando de "determinar prevalências absolutas de alguns direitos". Conforme assinalado, a ideia, ao contrário, é "presumir" tal escalonamento, o qual será apenas em abstrato (não absoluto), podendo, inclusive, "ser afastado, na apreciação de casos concretos, mediante justificação". ${ }^{75}$ Dessa feita, descreve a autora acerca da doutrina da posição preferencial, por ela tratada como "teoria das preferred freedoms", i. e., das "liberdades preferidas":

De acordo com essa formulação, as liberdades pessoais desfrutam de proteção constitucional mais intensa que os direitos de natureza econômica. Essa tutela especial é traduzida no emprego de pautas diferenciadas no controle de constitucionalidade das leis restritivas de cada tipo de liberdade. Quando se trata de direitos individuais, o teste de razoabilidade aplicado à legislação é mais severo, operandose uma inversão da presunção de constitucionalidade, que implica transferir para o Estado o ônus

71 PEREIRA, Jane Reis Gonçalves. Interpretação Constitucional e Direitos Fundamentai: uma contribuição ao estudo das restrições aos direitos fundamentais na perspectiva da teoria dos princípios. São Paulo: Renovar, 2006. p. 247.

72 PEREIRA, Jane Reis Gonçalves. Interpretação Constitucional e Direitos Fundamentai: uma contribuição ao estudo das restrições aos direitos fundamentais na perspectiva da teoria dos princípios. São Paulo: Renovar, 2006. p. 247-248.

73 PEREIRA, Jane Reis Gonçalves. Interpretação Constitucional e Direitos Fundamentai: uma contribuição ao estudo das restrições aos direitos fundamentais na perspectiva da teoria dos princípios. São Paulo: Renovar, 2006. p. 248.

74 MARTEL, Letícia de Campos Velho. Hierarquização de direitos fundamentais: a doutrina da posição preferencial na jurisprudência da Suprema Corte Norte-americana. Revista Sequência, Florianópolis, n. 48, p. 100, 2004.

75 PEREIRA, Jane Reis Gonçalves. Interpretação Constitucional e Direitos Fundamentai: uma contribuição ao estudo das restrições aos direitos fundamentais na perspectiva da teoria dos princípios. São Paulo: Renovar, 2006. p. 248. 
de provar que há um interesse público cogente a justificar a restrição. Já em matéria de regulação da atividade econômica, o controle é mais flexível, bastando que exista um interesse público legítimo. ${ }^{76}$

Letícia Campos Velho Martel, citando Christopher Wolfe, aponta etapas distintas da evolução de tal teoria:

Por intermédio do estudo dos casos que envolvem o devido processo legal substantivo, é possível identificar três etapas da doutrina da posição preferencial. A primeira, na qual ela não era propriamente uma doutrina, nem uma teorização, mas era utilizada, liga-se à Era Lochner, à época do economic substantive due process of law (1898-1937). A segunda, na qual não havia uma teorização explícita da doutrina, mas a Corte estava aderindo a outras doutrinas - teste do perigo claro e iminente e incorporação seletiva - que, quando aplicadas, recaíam na hierarquização de Direitos Fundamentais, iniciou-se ainda na Era Lochner, nos idos de 1920. A terceira, na qual, além da aplicação, houve a formulação teórica explícita da doutrina, com a adoção da terminologia preferred position, ou preferred freedoms, ou, em menor escala, preferred place, iniciou-se nos casos Carolene Products e Jones v. Opelika.(1938- dias atuais) e está ligada ao personal substantive due process of law. ${ }^{77}$

Com efeito, percebe-se que tal teoria se consolidou no âmbito jurisprudencial estadunidense no famigerado caso United States vs. Carolene Products Co., em que o Judice Stone proferiu em sentença (mais precisamente na nota de rodapé $\mathrm{n}^{\circ} 4$ ) as premissas de tal doutrina:

Deve existir um espaço mais estreito para a operacionalização da presunção de constitucionalidade quando a legislação recai facialmente em uma proibição da Constituição, como aquelas das dez primeiras Emendas, as quais são consideradas igualmente específicas quando agregadas à Décima Quarta. Veja-se Stromberg v. California, 283 U. S. 359, 283 U. S. 369-370; Lovell v. Griffin, 303 U. S. 444, 303 U. S. 452.

É desnecessário considerar agora se a legislação que constringe aqueles processos políticos, dos quais se pode ordinariamente esperar que causem repelência à legislação indesejada, devem ser sujeitas a um escrutínio mais rigoroso sob as proibições gerais da Décima Quarta Emenda do que a maior parte dos outros tipos de legislação. ${ }^{78}$

Sobre tal dispositivo paradigmático, discorre Letícia Martel:

$\mathrm{Na}$ referida nota de rodapé, considerada profética, tanto pela adesão que recebeu como pela sua repercussão no Direito Constitucional norte-americano no futuro, o Justice Stone elaborou ressalvas às afirmações que fizera no corpo do texto de Carolene Products. No voto, o Justice Stone afirmou que as regulações das liberdades e da propriedade somente deveriam ser declaradas inconstitucionais quando nenhuma base razoável fosse vislumbrada na correlação entre meios e fins, e que a Corte não poderia exigir mais do que isso, e, assim, asseverou o abandono da noção de que, em relação a alguns Direitos Fundamentais, a Corte deveria exigir uma relação clara e direta entre os fins e os meios. Já na nota de rodapé, o Justice Stone mitigou o alcance das palavras do voto, buscando não estender o princípio que nele firmara a outros Direitos Fundamentais que não as liberdades econômicas e a propriedade. Então, ao passo que a ratio decidendi estabelecida no voto conduzia ao fim do escrutínio estrito para certos Direitos Fundamentais, na nota de rodapé, Stone resguardou outros Direitos como aptos a ensejar o escrutínio estrito. $^{79}$

Esse sistema põe numa posição privilegiada as liberdades garantidas pelas emendas à Constituição norte-americana, culminando no que estabeleceu a $14^{a}$ Emenda, em sua seção $1^{a}$, quanto à cidadania — “Todas as pessoas nascidas ou naturalizadas nos Estados Unidos, e sujeitas a sua jurisdição, são cidadãos dos Estados

76 PEREIRA, Jane Reis Gonçalves. Interpretação Constitucional e Direitos Fundamentai: uma contribuição ao estudo das restrições aos direitos fundamentais na perspectiva da teoria dos princípios. São Paulo: Renovar, 2006. p. 248.

77 MARTEL, Letícia de Campos Velho. Hierarquização de direitos fundamentais: a doutrina da posição preferencial na jurisprudência da Suprema Corte Norte-americana. Revista Sequência, Florianópolis, n. 48, p. 100, 2004.

78 UNITED STATES OF AMERICA. SUPREME COURT. United States vs. Carolene products co. 304 u.s. 144, 1938. Footnote 4. Disponível em: <https://supreme.justia.com/cases/federal/us/304/144/case.html\#F4>. Acesso em: 14 jul. 2017.

79 MARTEL, Letícia de Campos Velho. Hierarquização de direitos fundamentais: a doutrina da posição preferencial na jurisprudência da Suprema Corte Norte-americana. Revista Sequência, Florianópolis, n. 48, p. 106-107, 2004. 
Unidos e do Estado onde tiverem residência". Essas liberdades preferidas, de tão íntimas do cidadão, enquadravam-se num patamar superior aos direitos e garantias constituídos apenas sob uma perspectiva econômica.

Tal hierarquização apontava para duas maneiras de deliberação por parte do juízo, uma mais rigorosa, determinada, submetida à superioridade dos preferred rights, em que não teria o ente julgador a liberalidade de decidir contra eles; e uma mais flexível, suave, na qual, por não se vislumbrar qualquer ameaça aos direitos privilegiados, teria o juízo maior liberdade de decidir. Mas de que forma tal teoria se aplicaria à questão do confronto entre direito ao esquecimento e o acesso à informação na internet? Justamente nos critérios que estabeleçam em que momento um direito é preferido em relação ao outro, notadamente o segundo em relação ao primeiro.

\subsection{Os requisitos para a preferência do acesso à informação na internet sobre o direito ao esquecimento}

Conforme o exposto, a posição preferencial define-se ao se revestirem os direitos preferidos de contornos de cidadania, encarados como superioridade em relação aos demais direitos que apenas se atenham a liberdades econômicas. No caso emblemático que deu origem à teoria, é fácil perceber a prevalência da informação da coletividade sobre o sigilo industrial. De igual forma, é forçoso reconhecer a preferência de um direito à informação da população sobre a privacidade de um político criminoso, por exemplo, que seja filmado numa reportagem com câmeras escondidas.

No caso do conflito entre o direito ao esquecimento e o acesso à informação via internet, no entanto, não é tão simples assim. Ocorre que nem sempre as informações veiculadas, sobretudo no perfil de mídia e de “jornalismo” que se percebe recorrentemente no Brasil, revestem-se dos necessários contornos cívicos que a teoria das liberdades preferidas reclama. Pelo contrário, muito se vê de excesso ou mesmo abuso de direito pelos profissionais do jornalismo, o que pode malferir também o direito ao esquecimento:

Os meios de comunicação, sob a premissa de informar a todo custo e uma falsa permissão ampla e irrestrita, por vezes invadem a esfera privada do indivíduo, retratando fatos e eventos indefinidamente no tempo, causando dano à dignidade humana das pessoas envolvidas. Tal cenário se torna ainda mais complexo quando se leva em consideração a internet, ambiente que, por excelência, não "esquece" o que nele é divulgado e pereniza tanto informações boas e ruins relativas à pessoa do noticiado, superando a contemporaneidade da notícia, sem esquecer, ainda, do alcance potencializado de divulgação próprio desse meio de comunicação, podendo ser, no mínimo, desconfortante àquele que é objeto da notícia. ${ }^{80}$

Nesses casos, o direito preferido é, em verdade, a defesa da dignidade do indivíduo contra a exploração econômica - feita, e. g., pelos meios de telecomunicação que ganham audiência com a revisita a fatos trágicos do passado. O direito ao esquecimento passa, assim, a receber maior destaque, como bem salienta Evilásio Ramos Filho:

Verifica-se que o direito ao esquecimento, a partir de uma nova realidade social que se vive nos dias atuais, sob a tônica da modernidade e ancorada na informação massificada, voltou a ser um tema atual e de inegável importância, em virtude dos danos causados por fatos e acontecimentos, falsos ou até mesmo verdadeiros, veiculados pelos diversos meios de comunicação, com o seu alto poder de propagação da informação, que inundam a esfera pública com episódios relacionados apenas à vida privada dos noticiados, que, muitas vezes, não possuem mais nenhuma relevância jornalística ou histórica e nenhum interesse social. ${ }^{81}$

80 RAMOS FILHO, Evilásio Almeida. Direito ao esquecimento versus liberdade de informação e de expressão: a tutela de um direito constitucional da personalidade em face da sociedade da informação. Monografia (Especialização) - Escola Superior da Magistratura do Estado do Ceará, Curso de Pós-Graduação Lato Sensu em Direito Constitucional, Fortaleza: ESMEC, 2014. p. 45. Disponível em: <http://portais.tjce.jus.br/esmec/wp-content/uploads/2014/12/Direito-ao-Esquecimento-vs-Liberdade-deInforma $\% \mathrm{C} 3 \% \mathrm{~A} 7 \% \mathrm{C} 3 \% \mathrm{~A} 30 . p d f>$. Acesso em: 29 jun. 2017.

81 RAMOS FILHO, Evilásio Almeida. Direito ao esquecimento versus liberdade de informação e de expressão: a tutela de um direito constitucional da personalidade em face da sociedade da informação. Monografia (Especialização) - Escola Superior da Magis- 
Nesse sentido, podemos facilmente vislumbrar quais requisitos seriam necessários para que, em vez de servir de meio para arbitrariedades, o acesso à informação via internet possa, sim, figurar como uma liberdade preferida. Os requisitos corresponderiam, justamente, ao que tornaria o exercício dessa liberdade realmente uma atividade cívica, pautada nos direitos de cidadania: veracidade das informações, zelo no trato com as informações, interesse histórico e social que reclame a (re)divulgação desses dados.

É nessa orientação que, mesmo no caso da Chacina da Candelária, em que se reconheceu ao autor o direito ao esquecimento, exigindo-se a supressão de seu nome, a conduta da reportagem não foi considerada ilícita. Uma vez que, realmente, seja pautada na ética, na relevância social das informações passadas e no respeito à dignidade humana, a informação figurará, sim, como uma liberdade preferida.

\section{Considerações finais}

A personalidade, enquanto projeção jurídica da condição humana, passava a ter sua própria categoria de direitos que lhe são caros, que lhe são vitais, essenciais. Dessa sorte, em sendo o gênero humano — ou própria personalidade humana - dinâmico por excelência, a Teoria dos Direitos da Personalidade tem incorrido numa dinamicidade igualmente grande. É nesse contexto que falamos no direito ao esquecimento.

Quer entendido como direito autônomo, quer, tal qual se defendera aqui, visto como "apenas" um desdobramento de direitos outros já consagrados, como a privacidade, a intimidade, a honra, a imagem, o segredo etc., podendo mesmos ser considerado com uma repercussão, ainda mediata, da própria liberdade e da dignidade humana. Esse direito, novo ou não, autônomo ou não, merece, sim, destaque, justamente porque assenta-se numa sociedade dita "da informação".

Nesse sentido, a pesquisa mostrou o caminho doutrinário percorrido para a consagração do direito ao esquecimento como prerrogativa do indivíduo, ali inserida na privacidade e liberdades mais básicas. Salientou-se, também, ainda persistir o conflito entre esse direito e uma liberdade clássica, vital, duramente conquistada após anos de censura, a liberdade de imprensa, e de seu principal desdobramento na Sociedade da Informação: o acesso às informações divulgadas na internet.

Como resultados, tem-se que, do conflito de dois valores tão constitucionalmente relevantes como estes, em inexistindo uma hierarquia entre eles, porque ambos constitucionais e fundamentais, a alternativa que resta é estabelecer um direito em preferência ao outro, no caso, do acesso à informação via internet sobre o direito ao esquecimento, segundo a interessantíssima "Teoria da Posição Privilegiada", criada pela Suprema Corte estadunidense. Ocorreu que, em se resgatando tal doutrina, verificou-se que a ideia de preferência se devia justamente ao caráter mais cívico, político e social dos direitos albergados pelas dez primeiras Emendas à Constituição do Estados Unidos da América, e pela $14^{a}$ Emenda, que replicou tais direitos ao plano dos estados.

Esse bloco de direitos, envoltos no próprio exercício da cidadania norte-americana, estaria numa posição preferencial àqueles direitos precípua ou exclusivamente pautados no patrimônio, na propriedade privada, na liberdade econômica. A informação dos cidadãos teria sempre preferência em relação ao sigilo industrial, por exemplo, conforme se entendeu no emblemático case envolvendo a empresa Carolene Products Co. Na atualidade, quando muito se vislumbra a liberdade de expressão e de acesso (à internet) para sua exploração econômica, muitas vezes antiética ou mesmo criminosa, o caráter cívico do direito de acesso à informação acaba prejudicado, merecendo maior atenção a privacidade, a identidade e a própria dignidade das pessoas atingidas pela veiculação de determinada informação na rede.

tratura do Estado do Ceará, Curso de Pós-Graduação Lato Sensu em Direito Constitucional, Fortaleza: ESMEC, 2014. p. 45. Disponível em: <http://portais.tjce.jus.br/esmec/wp-content/uploads/2014/12/Direito-ao-Esquecimento-vs-Liberdade-deInforma\%C3\%A7\%C3\%A3o.pdf>. Acesso em: 29 jun. 2017. 
Nesse sentido, chegou-se à conclusão de que, para serem efetivamente preferidas, as informações devem ser divulgadas segundo uma perspectiva realmente cívica, cidadã. Como requisitos para sua preferência, arrola-se a veracidade das informações, o manejo zeloso desses dados, a relevância histórica, científica e social que reclama um resgate de fatos delicados do passado, a preservação do nome dos envolvidos e o respeito à dignidade humana. Preenchidos tais padrões, há de se falar, sim, numa necessária preferência do direito à informação. Somente assim, há de se reportar sem recortar direitos, há de se informar sem deformar dignidades.

\section{REFERÊNCIAS}

ADAMS, Luís Inácio Lucena. Liberdade de Expressão e Democracia. Realidade intercambiante e necessidade de aprofundamento da questão. Estudo comparativo. A jurisprudência do Supremo Tribunal Federal no Brasil- Adpf 130- E a Suprema Corte dos Estados Unidos da América. Revista Brasileira de Políticas Públicas, Brasília, v. 5, n. esp., p. 439-450, 2015. Disponível em: <https://www.publicacoesacademicas.uniceub.br/ RBPP/article/view/3231/pdf>. Acesso em: 6 dez. 2017.

BARROS, Bruno Mello Correa de; OLIVEIRA, Rafael Santos de. O poder político e a mídia de massa: a perspectiva da fiscalização de concessões e outorgas de radiodifusão no Brasil. Rev. Bras. Polít. Públicas, Brasília, v. 7, n. 2, p. 368-383, 2017. Disponível em: <https://www.publicacoesacademicas.uniceub.br/ RBPP/article/view/4625/pdf>. Acesso em: 4 dez. 2017.

BARROSO, Luís Roberto. Colisão entre liberdade de expressão e direitos da personalidade: Critérios de ponderação: Interpretação constitucionalmente adequada do Código Civil e da Lei de Imprensa. Revisa de Direito Privado, v. 18, abr. 2004.

BARROSO, Luís Roberto. O controle de constitucionalidade no direito brasileiro: exposição sistemática da doutrina e análise crítica da jurisprudência. 6. ed. rev. e atual. São Paulo: Saraiva, 2012.

BATALHA, Taianne Nayrara Sampaio. Análise do direito ao esquecimento em face do princípio constitucional da vedação das penas de caráter perpétuo. Trabalho de Conclusão de Curso (Graduação) - Universidade Federal do Ceará, Faculdade de Direito, Curso de Direito, Fortaleza, 2014. Disponível em: <http://www.repositoriobib.ufc. br/000018/00001848.pdf>. Acesso em: 2 jul. 2017.

BITTAR, Carlos Alberto; BITTAR FILHO, Carlos Alberto. Direito civil constitucional. 3. ed. rev. e atual. São Paulo: Revista dos Tribunais, 2003.

BOFF, Salete Oro; DIAS, Felipe da Veiga. O acesso à informação no campo digital: uma análise entre a sociedade da informação e a sociedade de risco, Revista de Estudos Jurídicos, ano 16, n. 23, p. 329-344, 2012. Disponível em: <https://dialnet.unirioja.es/descarga/articulo/4816043.pdf>. Acesso em: 6 dez. 2017.

BRASIL. CONSELHO DA JUSTIÇA FEDERAL. CENTRO DE ESTUDOS JUDICIÁRIOS. VI Jornada de Direito Civil. Brasilia: CEJ, 2013. Disponível em: <http://www.cjf.jus.br/cjf/corregedoria-da-justica-federal/centro-de-estudos-judiciarios-1/publicacoes-1/jornadas-cej/vijornadadireitocivil2013-web.pdf/@@ download/file/VIJornadadireitocivil2013\%20web.pdf>. Acesso em: 9 jul. 2017.

BRASIL. Projeto de lei da câmara n. 7455, de 13 de maio de 2014. Brasília: Congresso Nacional, 2014. Disponível em: <http://www.camara.gov.br/proposicoesWeb/ fichadetramitacao?idProposicao=615049>. Acesso em: 15 set. 2017.

BRASIL. SUPERIOR TRIBUNAL DE JUSTIÇA. Recurso especial n. 1.334.097. Relator: Ministro Luiz Felipe Salomão. Brasília, DF, 28 de maio de 2013. Diário Oficial da União, Brasília, 10 jan. 2013. Disponível em: <http://www.stj.jus.br/SCON/jurisprudencia/doc.jsp?livre= resp+1334097+RJ\&\&b=ACOR\&p=tru 
e\&t=JURIDIC O\&l=10\&i=4>. Acesso em: 10 jul. 2017.

BRASIL. SUPERIOR TRIBUNAL DE JUSTIÇA. Recurso especial n. 1.335.153. Relator: ministro luiz felipe salomão. Brasília, DF, 28 de maio de 2013. Diário Oficial da União, Brasília, 10 set. 2013. Disponível em: <https://ww2.sti.jus.br/processo/revista/documento/mediado/?componente=ATC\&sequencial $=29411$ 308\&num_registro $=201100574280 \&$ data $=20130910 \&$ tipo $=91 \&$ formato $=P D F>$. Acesso em: 10 jul. 2017.

BRASIL. SUPREMO TRIBUNAL FEDERAL. Adi n. 815/DF. Relator: Min. MOREIRA ALVES, 28 de março de 1996. Órgão Julgador: TRIBUNAL PLENO. Diário da Justiça, 10 maio 1996. Disponível em: <https://stf.jusbrasil.com.br/jurisprudencia/744338/acao-direta-de-inconstitucionalidade-adi-815-df>. Acesso em: 29 out. 2017.

BONAVIDES, Paulo. Curso de Direito Constitucional. 19. ed. São Paulo: Ed. Malheiros, 2006.

CARVALHO, Salo de. Antimanual de criminologia. 5. ed. São Paulo: Saraiva, 2013.

CASTRO, Carlos Roberto Siqueira. A constituição aberta e os direitos fundamentais: ensaios sobre o constitucionalismo pós-moderno e comunitário. 2. ed. Rio de Janeiro: Forense, 2010.

CAVALCANTE, Márcio André Lopes. Direito ao esquecimento. Disponível em: <https://www.buscadordizerodireito.com.br/jurisprudencia/detalhes/75fc093c0ee742f6dddaa13fff98f104>. Acesso em: 15 dez. 2017.

D’AGOSTINO, Rosanne. Três anos depois, linchamento de Fabiane após boato na web pode ajudar a endurecer lei. G1, É ou não é?, São Paulo, 1 abr. 2017. Disponível em: <https://g1.globo.com/e-ou-nao-e/ noticia/tres-anos-depois-linchamento-de-fabiane-apos-boato-na-web-pode-ajudar-a-endurecer-lei.ghtml $>$. Acesso em: 25 set. 2017.

DIAS, Felipe da Veiga; CUSTÓDIO, André Viana. O discurso expansivo-punitivo dos meios de comunicação e sua influência na formação da agenda das políticas públicas de combate à criminalidade de crianças e de adolescentes no Brasil. Revista Brasileira de Políticas Públicas, Brasília, v. 3, n. 1, p. 91-104, jan./jun. 2013. Disponível em: <https://www.publicacoesacademicas.uniceub.br/RBPP/article/view/2162/pdf>. Acesso em: 7 dez. 2017.

DINIZ, Igor Vinicius de Lucena; COSTA, Lucas dos Santos; MEDEIROS, Marcos Fernando M. Utilização da computação em nuvem no poder legislativo: percepções dos gestores e entraves ao uso. Rev. Bras. Polit. Públicas, Brasília, v. 7, n. 1, p. 264-285, 2017. Disponível em: <https://www.publicacoesacademicas.uniceub. br/RBPP/article/view/4586/pdf>. Acesso em: 6 dez. 2017.

HILBERT, Martin. How much information is there in the world? Science Daily, Science News, 11 fev. 2011. Disponível em: <https://www.sciencedaily.com/releases/2011/02/110210141219.htm>. Acesso em: 20 set. 2017.

HOUAISS, Antônio; VILLAR, Mauro; FRANCO, Francisco Manoel de Mello. Dicionário Houaiss da língua portuguesa. Rio de Janeiro: Objetiva, 2009.

KELSEN, Hans. Teoria Pura do Direito. Coimbra: Armênio Amado, 1979.

LADEUR, Karl-Heinz. New institutions for the protection of privacy and personal dignity in internet communication - "information broker", "private cyber courts" and network of contracts. Revista Brasileira de Políticas Públicas, Brasília, v. 10, n. 1, p. 281-296, 2013. Disponível em: <https://www.publicacoesacademicas. uniceub.br/RBPP/article/view/2531/pdf_1>. Acesso em: 6 dez. 2017.

LIMA, Cíntia Rosa de. Direito ao Esquecimento e Internet: o fundamento legal no Direito Comunitário europeu, no Direito italiano e no Direito brasileiro. Revista dos Tribunais, n. 946, ago. 2014. Disponível em: $<$ http:/ / revistadostribunais.com.br/maf/app/resultList/document?\&src $=$ rl\&srguid $=i 0 a d 818160000014$ 8eaba22 4209ca070c\&docguid =I273372f00d7711e4a04c010000000000\&hitguid =I273372f00d7711e4a0 $4 \mathrm{c} 01000000000$ 0\&spos $=4 \&$ epos $=4 \& \mathrm{td}=7 \&$ context $=8 \&$ startChunk $=1 \&$ endChunk $=1>$. Acesso em: 9 jul. 
2017.

LIMA, George Marmelstein. A hierarquia entre princípios e a colisão de normas constitucionais. Revista Jus Navigandi, Teresina, ano 6, n. 54, fev. 2002. Disponível em: <http://jus2.uol.com.br/doutrina/texto. asp?id $=2625>$. Acesso em: 7 dez. 2017.

LOPES, Ana Maria D’Ávila. Hierarquização de Direitos Fundamentais? Revista de Direito Constitucional e Internacional - IBDC, São Paulo, ano 9, jan./mar. 2001.

LUÑO, Antonio-Enrique Pérez. Teledemocracia, ciberciudadania y derechos humanos. Revista Brasileira de Políticas Públicas, Brasília, v. 4, n. 2, p. 8-46, 2014. Disponível em: https://www.publicacoesacademicas.uniceub.br/RBPP/article/view/2835/pdf>. Acesso em: 5 dez. 2017.

MARTEL, Letícia de Campos Velho. Hierarquização de direitos fundamentais: a doutrina da posição preferencial na jurisprudência da Suprema Corte Norte-americana. Revista Sequência, Florianópolis, n. 48, 2004.

MENDES, Gilmar Ferreira. Colisão de direitos fundamentais na jurisprudência do Supremo Tribunal Federal. Repertório de Jurisprudência IOB, São Paulo, v. 1, n. 5, p. 178-185, mar. 2003.

MENDES, Gilmar Ferreira; COELHO, Inocêncio Mártires; BRANCO, Paulo Gustavo Gonet. Curso de Direito Constitucional. São Paulo: Saraiva, 2007.

MIRANDA, Francisco Cavalcanti Pontes de. À margem do direito: ensaio de psychologia jurídica. Rio de Janeiro: Francisco Alves \& Cia, 1912.

MIRANDA, Francisco Cavalcanti Pontes de. Tratado de Direito Privado: direitos da Personalidade, direito de Família. Rio de Janeiro: Rio de Janeiro, 1955. t. 7.

ORGANIZAÇÃO DAS NAÇÕES UNIDAS. ASSEMBLEIA GERAL. Declaração universal dos direitos humanos, Resolucão 2017, A, III, de 10 de dezembro de 1948. Disponível em: < https://www.unicef.org/brazil/pt/ resources_10133.htm>. Acesso em: 6 dez. 2017.

PAES, Luciano Marcos. Participação popular e acesso à informação ambiental para preservação do meio ambiente ecologicamente equilibrado. Revista Brasileira de Políticas Públicas, Brasília, v. 5, n. 2, p. 277-287, 2015. Disponível em: <https://www.publicacoesacademicas.uniceub.br/RBPP/article/view/3561/pdf_1>. Acesso em: 6 dez. 2017.

PEREIRA, Caio Mario da Silva. Instituições de direito civil: parte geral. 12. ed. rev. e atual. Rio de Janeiro: Forense, 2007. v. 1.

PEREIRA, Jane Reis Gonçalves. Interpretação Constitucional e Direitos Fundamentai: uma contribuição ao estudo das restrições aos direitos fundamentais na perspectiva da teoria dos princípios. São Paulo: Renovar, 2006.

RAMOS FILHO, Evilásio Almeida. Direito ao esquecimento versus liberdade de informação e de expressão: a tutela de um direito constitucional da personalidade em face da sociedade da informação. Monografia (Especialização) - Escola Superior da Magistratura do Estado do Ceará, Curso de Pós-Graduação Lato Sensu em Direito Constitucional, Fortaleza: ESMEC, 2014. Disponível em: <http://portais.tjce.jus.br/esmec/ wp-content/uploads/2014/12/Direito-ao-Esquecimento-vs-Liberdade-de-Informa\%C3\%A7\%C3\%A3o. pdf>. Acesso em: 29 jun. 2017.

RODRIGUES JÚNIOR, Otavio Luiz. Brasil debate direito ao esquecimento desde 1990. Consultor Jurídico, 27 nov. 2013. Disponível em: <http://www.conjur.com.br/2013-nov-27/direito-comparado-brasil-debatedireito-esquecimento-1990>. Acesso em: 10 jul. 2017.

SANTANA, Héctor Valverde; VIANA, Rafael Souza. O compartilhamento de dados e informações pessoais de consumidores: o abuso dos fornecedores e as propostas apresentadas no PLS 181/2014. Rev. Bras. Polit. Públicas, Brasília, v. 7, n. 1, p. 246-263, 2017. Disponível em: <https://www.publicacoesacademicas. uniceub.br/RBPP/article/view/4579/pdf>. Acesso em: 5 dez. 2017. 
SILVA, Virgílio Afonso da. Interpretação Constitucional e Sincretismo Metodológico. In: SILVA, Virgílio Afonso da (Org.). Interpretação constitucional. São Paulo: Malheiros, 2009.

SUNSTEIN, Cass. Republic.com. Princeton: University Press, 2001.

UNITED STATES OF AMERICA. Constitution of the United States: $14^{\text {th }}$ amendment. Disponível em: $<$ http://www.senate.gov/civics/constitution_item/constitution.htm\#amdt_14_(1868)>. Acesso em: 14 jul. 2017.

UNITED STATES OF AMERICA. SUPREME COURT. United States vs. Carolene products co. 304 u.s. 144, 1938. Footnote 4. Disponível em: <https://supreme.justia.com/cases/federal/us/304/144/case.html\#F4>. Acesso em: 14 jul. 2017. 
Para publicar na revista Brasileira de Políticas Públicas, acesse o endereço eletrônico www.rbpp.uniceub.br

Observe as normas de publicação, para facilitar e agilizar o trabalho de edição. 